\title{
Intellectual Property Rights Protection, Ownership, and Innovation: Evidence from China
}

\section{Citation}

Fang, Lily, Josh Lerner, and Chaopeng Wu. "Intellectual Property Rights Protection, Ownership, and Innovation: Evidence from China." Harvard Business School Working Paper, No. 17-043, November 2016.

\section{Permanent link}

http://nrs.harvard.edu/urn-3:HUL.InstRepos:30861195

\section{Terms of Use}

This article was downloaded from Harvard University's DASH repository, and is made available under the terms and conditions applicable to Open Access Policy Articles, as set forth at http:// nrs.harvard.edu/urn-3:HUL.InstRepos:dash.current.terms-of-use\#OAP

\section{Share Your Story}

The Harvard community has made this article openly available.

Please share how this access benefits you. Submit a story.

Accessibility 


$$
\text { H A R VAR D B US INESS S C HOOL }
$$

\section{Intellectual Property Rights Protection, Ownership, and Innovation: Evidence from China}

Lily Fang Josh Lerner

Chaopeng $\mathrm{Wu}$

Working Paper 17-043 


\title{
Intellectual Property Rights Protection, Ownership, and Innovation: Evidence from China
}

\author{
Lily Fang \\ INSEAD
}

Josh Lerner

Harvard Business School

Chaopeng Wu

Xia Men University

Working Paper 17-043 


\title{
Intellectual Property Rights Protection, Ownership, and Innovation: \\ Evidence from China
}

November 21, 2016

\author{
Lily Fang* \\ INSEAD \\ Josh Lerner \\ Harvard University and NBER \\ Chaopeng $\mathrm{Wu}$ \\ Xia Men University
}

\begin{abstract}
Using a difference-in-difference approach, we study how intellectual property right (IPR) protection affects innovation in China in the years around the privatizations of state-owned enterprises (SOEs). Innovation increases after SOE privatizations, and this increase is larger in cities with strong IPR protection. Our results support theoretical arguments that IPR protection strengthens firms' incentives to innovate and that private sector firms are more sensitive to IPR protection than SOEs.
\end{abstract}

Key words: Patents; Legal Institutions; Development; China

JEL Classification: O31, O34, O38

Send all correspondences to: Lily Fang, INSEAD, 1 Ayer Rajah Avenue, Singapore 138676. Tel: +65-6799-5376. Email: lily.fang@insead.edu. We are grateful for the helpful comments from Andrew Karolyi and two anonymous referees. We thank Harvard Business School's Division of Research for their financial support. Patent Sight provided helpful data. Di Tang at Xia Men University helped with data collection. Seminar audiences at the American Economic Association annual meeting, Cornell University, London Business School, the NBER China Economy meeting (especially our discussant, Ufuk Akcigit), the Tsinghua PBSCF Conference on Entrepreneurial Finance and Innovation Around the World (especially our discussant, T.J. Wong), and the University of Pennsylvania provided helpful comments. Any errors and omissions are our own. 


\section{Introduction}

Harkening back to Schumpeter (1934), the literature on law and finance argues that effective legal and financial institutions lead to better economic outcomes (e.g., King and Levine 1993; La Porta, Lopez-de-Silanes, Shleifer, and Vishny 1998; Rajan and Zingales 1998). But China's rapid economic growth in the past thirty years raises questions about this view. As Allan, Qian, and Qian (2005) point out, China has achieved the fastest sustained growth in history despite having poor legal and financial institutions. This suggests that, at least in the case of China, good institutions may not be necessary for economic development.

Instead, the economic development model China has followed in the past thirty years relies on a strong state sector. Many state owned enterprises (SOEs), under state direction and protection, are the country’s most visible symbols of economic prowess. China's state sector plays such a key role in the economy that the nation is often regarded as an example of "state capitalism" (See, for example, “The rise of state capitalism” 2012). These observations raise the following question: What is the efficacy of ownership as a source of incentives in a setting with poor institutions?

In this paper, we examine this question by focusing on innovation, an activity that Schumpeter identified as critical to economic change. In this context, institutional quality is gauged by the strength of intellectual property right (IPR) protection. The central empirical question we examine is how institutional quality (IPR protection) and ownership type (state backing or not) jointly affect Chinese firms' innovative output. Specifically, we shed light on the following three questions:

1. Where has China's innovation taken place: in state-owned enterprises (SOEs) or in private sector firms?

2. Are legal institutions - in particular, IPR protection - important for innovation within China? 
3. If so, are SOEs or private sector firms more sensitive to IPR protection?

China's ability to innovate is not only an interesting and relevant question for economists, but also a timely matter of first-order policy importance to the Chinese. Since China's economic reforms started in the late 1970s, the country's growth has largely relied on cheap labor and stateled investments in physical infrastructure. But as China's labor costs have surged and growth rates have declined in recent years, this growth model has been widely seen as obsolete. China's top leaders are promoting innovation as the key to the country's sustained economic growth: for instance, in the $13^{\text {th }}$ Five-Year Plan released in March 2016, innovation was listed as the first guiding principle of economic policy. ${ }^{1}$ But the extent to which the state can drive innovation without sound institutions and economic incentives remains in question.

There are two competing hypotheses about where innovation is likely to take place and the importance of IPR protection in China. Entrepreneurs' incentives to innovate-what Schumpeter terms the "entrepreneurial spirit" - depend on their ability to capture the profit from innovation, which in turn depends on IPR protection and institutions such as the patent system. The danger of ex post expropriation as a result of poor IPR protection will deter innovation, consistent with arguments in Nelson (1959) and Arrow (1962). This line of reasoning concludes that, in China, precisely because private firms face a high risk of expropriation, institutional quality such as IPR protection standards should be particularly important for innovation in the private sector. We call this the "Schumpeterian view."

\footnotetext{
${ }^{1}$ See http://www.apcoworldwide.com/docs/default-source/default-document-library/Thought-Leadership/13-fiveyear-plan-think-piece.pdf?sfvrsn=2 (accessed April 27, 2016) for information on and analyses of the most recent Five-Year Plan. Five-year plans are China's top policy blueprints containing its social, economic, and political goals. As the name suggests, each plan covers a five-year period. The $13^{\text {th }}$ Five-Year Plan (the most recent) covers 2016 to 2020.
} 
On the other hand, despite the country's poor record of IPR protection, China has in recent years become the most prolific patent-filing country in the world. ${ }^{2}$ One explanation for this paradox is that in the absence of legal protection, state ownership acts as an alternative mechanism, giving state-owned firms both incentives (or directives) for innovation and protection against expropriation. SOEs in China, in fact, have a two-tiered defense against expropriation: through administrative measures by the government (the firms' owners), and through the courts, which are often biased in their favor (Snyder 2012). This explanation suggests that China's innovation should be led by the SOEs, and because they rely on the state, institutions such as IPR protection do not matter much. We call this the "alternative mechanisms view."

To test these hypotheses, we compare firm-level innovation (based on patent activity) of SOEs and private firms across Chinese cities with varying levels of IPR protection. We do not, however, undertake a simple cross-sectional comparison, because doing so raises two endogeneity concerns. First, SOEs and private firms are inherently different: their geographic and industry distribution is non-random and may be related to the quality of local IPR protection. Second, even the quality of local IPR protection itself can be an endogenous outcome of local innovative activities (and hence demand for IPR protection), rather than having a causal effect on innovation.

To address these empirical challenges, we exploit China's privatizations of SOEs as an identification method. The idea is that the privatization events result in a sharp change in the firms' ownership structures and state affiliations, while keeping other firm attributes fixed. We can therefore compare the rates of innovation before and after the change in ownership within the same firm. By studying this before-and-after difference in innovation rates across firms in regions with

\footnotetext{
${ }^{2}$ World Intellectual Property Indicators 2014 from the World Intellectual Property Organization, http://www.wipo.int/edocs/pubdocs/en/wipo_pub_941_2014.pdf (accessed April 6, 2016).
} 
varying local IPR protection standards, we can identify the joint effect of ownership type and IPR protection. In essence, these events allow us to use a difference-in-difference method.

For SOE privatizations to be a valid identification instrument, however, it is crucial that these events be exogenous to the innovation process. ${ }^{3}$ Our identification approach would be problematic, for example, if innovative firms and entrepreneurs felt shackled by state ownership and initiated privatizations precisely in order to engage in more innovation. Fortunately, this concern is allayed by China's political economic history. SOE privatizations and restructurings were key policy initiatives of China’s top leaders from 1996 to 2005 (the ten-year period covering the $9^{\text {th }}$ and $10^{\text {th }}$ Five-Year Plans). This policy drive led to a massive and sweeping privatization wave, which by some estimates ultimately privatized two-thirds of the state sector (Gan 2009). The overarching goal of these privatizations was to increase the efficiency of China's vast state sector and to transition the country from central planning to a market orientation. By way of contrast, innovation became a policy focus quite recently.

We document three main findings. First, innovation increases significantly after firms are privatized. On average, firms' patent stock increases by $200 \%$ to $300 \%$ in the five years after privatization compared to the five years before. Second, the increase in innovation is significantly larger in cities with high IPR protection than in cities with low IPR protection. A one standarddeviation increase in local IPR protection score nearly quadruples the post-privatization increase in patent stock. ${ }^{4}$ Third, we find evidence that patents of private sector firms are cited more often and have a greater international presence - in other words, are of higher quality - than patents of SOEs, suggesting that the increase in patent filings is not a consequence of "window dressing." In

\footnotetext{
${ }^{3}$ Fan, Wong, Zhang (2013) discusses the endogenous nature of state ownership structure.

${ }^{4}$ In results not reported in this version, we confirm these findings in the opposite type of ownership change: nationalizations.
} 
sum, our evidence is strongly supportive of the Schumpeterian view that institutions matter, even in China. It is inconsistent with the alternative mechanisms view.

We believe our paper makes two key contributions to the literature and to the policy discussion. First, we contribute to the empirical literature on the relationship between IPR protection and innovation, and more broadly, on institutions and growth. Many papers in the existing literature are based on cross-country evidence, which is subject to endogeneity concerns and unobservable heterogeneity. By focusing within one country and using the unique identification strategy afforded by the privatization events, our paper improves on and adds to the existing empirical evidence.

Our second key contribution is to the policy discussion. China’s stellar economic growth in the last thirty years has led some scholars to argue that the nation is an exception rather than the rule when it comes to economic development. For instance, Allen, Qian, and Qian (2005) propose that instead of formal institutions, China's economic development is supported by informal mechanisms such as trust and relationships. Our evidence in this paper shows that there is a limit to this argument. When it comes to innovation, institutional quality does matter, and it particularly matters to private sector innovation, the source of more impactful and important technological advancement. Our evidence suggests that the success of the current efforts by Chinese policymakers to shift to an innovation-driven economy will depend on building more robust institutions. $^{5}$

\section{Data and Descriptive Statistics}

\footnotetext{
${ }^{5}$ Our conclusion is broadly consistent with and related to that of Aghion, et al. (2015), which studies a comprehensive sample of medium- and large-sized firms in China and concludes that industrial policies that foster competition enhance productivity growth. Both that paper and ours indicate the importance of market-based mechanisms for China's future productivity growth.
} 


\section{A. IPR Protection in China}

China began formal recognition and protection of IPR in 1980, when it became a member of the World Intellectual Property Organization. It patterned its IPR law on the Berne Convention for the Protection of Literary and Artistic Works and the Agreement on Trade-Related Aspects of Intellectual Property Rights. The letter of the law governing IPR is consistent with international standards and is the same across the entire country. In practice, however, evidence abounds that China generally has a poor record on IPR protection and that significant variations exist across regions in their interpretation and enforcement of IPR law.

In China, IPR protection matters at a local level for several reasons. First, there is very little forum shopping in China. Unlike in the U.S., where firms can choose the court to file law suits, which renders the local legal environment less relevant, the Chinese Intellectual Property Law stipulates that plaintiffs can only file lawsuits either in the location of their domicile or where the violation occurred, i.e., the location of the defendant. ${ }^{6}$ Reflecting both the lack of forum-shopping and the clustering of many industries, $80 \%$ of the IPR cases in the Chinese Judicial Case Database ${ }^{7}$ involve both plaintiffs and defendants from the same province. Second, filing for international patent protection is still rare among Chinese firms. Even among the most prolific Chinese patent filers, $81 \%$ do not have U.S. filings, and over $90 \%$ do not have Japanese or European filings. International filing rates would be even lower for the average firm, especially the non-listed firms in our sample. ${ }^{8}$ Finally, most of the companies are focused on the domestic market: $70.2 \%$ of the

\footnotetext{
${ }^{6}$ See Rule 81 of the Chinese Intellectual Property Law Implementation Details. http://www.scipo.gov.cn/zcfg/fljzcfg/201504/t20150422_15458.html (accessed May 2, 2016).

7 This is the largest legal case database in China, and it is maintained by the Beijing University. http://www.pkulaw.cn/case (accessed April 15, 2016).

${ }^{8}$ International filing rates are estimated based on a sample of 331 most prolific Chinese patent filing companies provided to us by Patent Sight. The average firm size in our unlisted sample is 65 million RMB in total assets (roughly 8 million USD based on an exchange rate of 1 USD $=8 \mathrm{RMB}$, approximately the prevailing rates between 2002 and 2006, the peak of the privatization wave), and 1.2 billion RMB (roughly 150 million USD) in total assets
} 
firms in our sample report no export revenue. Of those that report exports, these account for just under $20 \%$ of total sales. Thus, their patent litigation is likely to occur primarily in the Chinese court system rather than in foreign courts. ${ }^{9}$

Empirically, Ang, Cheng, and Wu (2014) demonstrate not only that there is significant heterogeneity in local IPR protection within China, but also that this variation leads to divergent economic outcomes. They examine the plaintiffs' win rates in IPR lawsuits across Chinese provinces, and find that this rate ranges from $25 \%$ to $87 \%$, a large variation given the null of $50 \%$ predicted by theory (Priest and Klein 1984). ${ }^{10}$ They show that this regional variation in IPR protection is related to firms' financing choices, R\&D investments, and patenting. Hsu, Wang, and Wu (2013) show that local IPR protection reduces piracy and enhances firm value.

Measuring the quality of IPR protection and relating it to innovation is challenging, however, because many obvious types of IPR protection measures suffer from reverse causality concerns. For example, measures based on the existence and provisions of IP laws or the quantity of legal professionals are subject to the concerns that laws and the legal profession evolve endogenously in response to firms’ demands for IPR protection, rather than causing innovation. In any event, measures based on legal provisions are infeasible in our context, as our goal is to measure local IPR protection within a single country which has no variation in the letter of the law. Ang, Cheng, and Wu (2014) construct two novel measures of regional IPR protection in China, one based on plaintiff win rates in provincial courts and another based on the frequency of media

in the listed sample (details of our firm sample is discussed in Section 1.C.) Given the small firm size, international filing would be very rare, though we do not have detailed statistics.

${ }^{9}$ Keller (2002) argues that technology is largely local, not global, as he shows that the benefits from technology spillovers decline with distance.

${ }^{10}$ Priest and Klein (1984) argue that a plaintiff's decision to litigate is endogenous and takes into account the costs and benefits of litigation. Consequently, the win rates in all courts, whether pro-plaintiff or pro-defendant in orientation, should converge to $50 \%$. 
mentions of IPR in Chinese official newspapers. But these measures are difficult to interpret ${ }^{11}$ and raise reverse causality concerns.

To overcome these difficulties, we use a survey-based prefecture level IPR index published by the Chinese Academy of Social Sciences (CASS), the leading research institution on social and economic issues in China. Between 2002 and 2011, ${ }^{12}$ the CASS published an annual Urban Competitiveness Report based on detailed surveys of 66 prefectures ${ }^{13}$ in China across 25 provinces. ${ }^{14}$ The report contains separate rankings of the prefectures along many dimensions, such as IPR protection, business openness, talent availability, and livability. The IPR protection ranking is based on a survey of legal professionals including judges, IPR lawyers, and corporate executives, such as CEOs and technical heads. The annual survey contains on average over 6,000 responses, or roughly 100 per prefecture surveyed. The format of the survey follows "The Competitiveness of Cities” report published by the World Economic Forum. Specifically, it asks the respondents to rate from 5 (best) to 1 (worse) three areas relating to local IPR enforcement:

1) The length of time it takes for courts to resolve IP disputes,

2) The cost of resolving the dispute as a percentage of the value of the IP under dispute,

3) The fairness of court decisions.

The responses to each of the three questions from each prefecture are aggregated as follows:

\footnotetext{
${ }^{11}$ For instance, a higher plaintiff win rate could indicate more severe IPR infringements rather than better protection, and more frequent media mentions could also reflect more IPR violations.

12 The CASS continued to publish annual Urban Competitiveness Reports after 2011, but used a different methodology. To maintain data consistency, our analysis uses data up to 2011. In robustness checks, we find our results to be qualitatively and quantitatively very similar if we extend the sample through 2013.

${ }^{13}$ A prefecture is an administrative division, ranking below a province and above a county in China's administrative structure. A prefecture is larger than a "city" in the usual sense of the term (i.e., a continuous urban settlement). It is an administrative unit comprised of a main central urban area (usually with the same name as the prefecture) and its larger surrounding rural area, containing many smaller cities, towns, and villages.

${ }^{14}$ Mainland China has 31 provincial-level entities, including four provincial-level municipalities (Beijing, Tianjin, Shanghai, and Chongqing), and five autonomous regions. The four provincial-level municipalities are each considered as a prefecture for the purposes of this analysis. The six provinces/regions that are not in the survey are Gansu, Guizhou, Qinghai, Ningxia Hui Autonomous Region, Xingjian Uyghur Autonomous Region, and Tibet Autonomous Region.
} 
Prefecture Response $=(-2) * w_{1}+(-1) * w_{2}+(0) * w_{3}+(1) * w_{4}+(2) * w_{5}$

where $w_{1}-w_{5}$ are the proportion of responses from 1 to 5 , respectively. The responses to the three questions are then averaged, and based on this average, a prefecture's final IPR score is calculated as follows:

Prefecture IPR Score $=\frac{\text { Prefecture Average Response }}{\text { Max(Prefecture Average Response })}$

where max(Prefecture Average Response) is the maximum response across all 66 prefectures. Therefore, the ultimate score reflects a percentage of the highest score.

The advantage of this survey-based measure is that it directly reflects the perceived quality of IPR protection, which affects the incentives to innovate. ${ }^{15}$ Within China, this IPR measure is widely used by top government entities, including the State Council (China's top administrative authority), the National Reform and Development Commission, and the China Academy of Urban Planning and Design.

Figure 1 provides a provincial map of China and shows the regional variations in IPR protection. Our data are at the prefecture level, but we aggregate the data to the province level here for ease of presentation. Thus, the map does not fully represent the heterogeneity in the data. But even at this coarse level, we see significant variations across regions. Unsurprisingly, coastal areas, such as Shanghai, Jiangsu, and Zhejiang, have the highest levels of IPR protection. But there are notable exceptions. For example, Guangdong Province, which is one of the most developed regions with the highest per capita GDP, is not among the group of provinces with the highest IPR

\footnotetext{
${ }^{15}$ We calculated the correlation between our survey-based measure and the two provincial-level measures used by Ang, et al. (2014). We find that the correlation between our measure and plaintiff win rate measures is $18 \%$ and the correlation between our measure and the media-based measure is $35 \%$, both significantly different from zero. Our results are robust to using these alternative measures.
} 
protection scores, while inland, poorer provinces such as Anhui and Guangxi are. In our empirical analysis, we control for provincial fixed effects to remove any region-level effects.

Table 1 provides summary statistics of the IPR protection data aggregated at the province level. The 25 provinces in the sample are listed in ascending order of the average IPR score. The table reveals significant time series and cross-sectional variation in local IPR scores. Take Shanghai, for instance. Since it is a single prefecture, the variation in its IPR score is a function of time only. The table shows that its highest score was 1 , meaning it was the prefecture with the highest raw score (this was achieved in 2007), and its lowest score was 0.69 (this occurred in 2006). There are also significant variations across prefectures within the same province. For instance, Jiangsu Province has an average IPR score of 0.76, ranking second highest among all provinces. Its highest score was also 1 (obtained by Wuxi City in 2005) and its lowest score was 0.42 (Changzhou City in 2003). It might be conjectured that IPR scores are highly correlated with a region's coastal status. However, this conjecture overlooks the heterogeneity within provinces. While the correlation between the mean (maximum) IPR score and the coastal status of a province is $0.68(0.48)$, the correlation between the minimum IPR score in a province and the coast status is only 0.12 . Thus, even in wealthy coastal provinces with relatively high average IPR scores, there are prefecture-years where the IPR scores are low. This richness in the IPR data is ideal for our identification strategy, which relies on SOE privatizations that occur in many different prefectures and over a decade.

Figure 2 depicts the mean IPR trend over our sample period. We use the median in each year to divide the sample into a "high IPR" and a "low IPR" group and plot the means of each group. Since the IPR score is a percentage of the highest score, the mean indicates whether various prefectures are converging to the "best," or diverging from it. It is interesting to note that the mean 
of both groups steadily rose between 2002 and 2009, but declined slightly afterwards. This means that while perceived IPR protection quality has generally increased and converged across prefectures, the trend shows some sign of reversing.

\section{B. Patents}

We use patents to measure firm-level innovation. Equating patents to innovation is clearly imperfect, as noted by the literature on innovation. For example, Jaffe and Lerner (2004) document numerous problems in the U.S. patent system in the last two decades, including trivial patents being awarded and companies hoarding patents to engage in abusive, anti-competitive behaviors. More recent empirical evidence has shown that strong IPR protection can encourage patent assertion entities (colloquially known as "trolls”) who deter subsequent innovation (e.g., Cohen, Gurun, and Kominers 2016; Williams 2013). Despite their limitations, patents remain a standard measure of innovation. Moreover, many of the recent problems documented in the U.S. are likely confined to highly evolved patent systems, unlike China.

We manually collect patent data for Chinese firms from the website of the Chinese State Intellectual Property Office (CSIPO), China's counterpart to the United States Patent and Trademark Office (USPTO). ${ }^{16}$ The Chinese patent application procedure is similar to that in the U.S. and Europe. Before filing an application, the applicant is encouraged to search existing patent and publication databases to ensure the novelty of the application. After undertaking its own examination, the CSIPO grants two types of patents for innovation: invention and utility. ${ }^{17}$ Invention patents have the highest innovative content, as they cover novel technologies. Utility

\footnotetext{
16 http://epub.sipo.gov.cn/gjcx.jsp (accessed May 2, 2016).

17 There is a third patent category, design patents. These patents cover novel packaging and design. For the purpose of this study, we focus only on invention and utility patents.
} 
patents cover new applications of existing technologies. The innovative content in each type of patent is reflected in the length of time required to obtain the patent. Invention patents involve two rounds of officer examination (preliminary and detailed examinations) lasting 18 to 36 months. Utility patents require one round of examination that lasts from three to six months. Statistics from 2012 indicate that the application success rates are 33\% and 77\%, respectively, for innovation and utility patents. $^{18}$

Following prior work (e.g., Griliches 1984; Hall 1993; Hall, Jaffe and Trajtenberg 2005), to reflect the long-term nature of patent assets, we construct the patent stock measure as follows: ${ }^{19}$

$$
K_{i, t}=(1-\theta) K_{i, t-1}+r_{i, t}
$$

where

- $K_{i, t}$ is the patent stock of firm $i$ in year $t$,

- $\theta$ is the rate of depreciation of the patent stock, which is set to $15 \%$ in accordance with prior work, and

- $r_{i, t}$ is the ultimately granted patents applied for by firm $i$ in year $t$.

Figure 3 plots the average patent stock (scaled by million RMB in assets) for listed Chinese companies between 1992 and 2013. We present private firms and SOEs separately (the identification of these firm types is discussed in detail in the next sub-section). The figure shows a steady increase of patent stock over time among both sets of firms. Notably, growth in the patent stock among private firms accelerates after 2004, surpassing the patent stock of SOEs. In unreported statistical tests, we find that the difference between the two sets of firms is highly significant after 2006: SOEs dominated China's innovation in early years but were then surpassed

\footnotetext{
${ }^{18}$ For more information, see the CSIPO website (accessed May 2, 2016), http://epub.sipo.gov.cn/gjcx.jsp.

${ }^{19}$ Our results are robust to using flow measures of patents. Unreported results are available upon request.
} 
by private firms. Coincidentally, 2006 was a pivotal year in China's recent economic history: in that year, China agreed to follow the conventions set out by the World Trade Organization and fully implemented the revisions of its IPR legal framework, thus significantly strengthening its IPR protection.

\section{SOE Privatizations}

In China's transformation from a centrally planned economy to a market-oriented one, the country experienced the largest wave of SOE privatization in history (Gan 2009). Large-scale SOE privatizations began in the mid-1990s as part of broad economic reforms outlined in the $9^{\text {th }}$ and $10^{\text {th }}$ Five-Year Plans. Gan, Guo, and Xu (2008) estimate that between 1995 and 2005, firms with an aggregate 11.4 trillion RMB in assets were privatized in China, comprising two-thirds of China's SOE and state assets.

These sweeping privatizations were part of China's overall economic reform, rather than the result of a desire to enhance innovation. Figure 4 supports this notion. We searched the key words "privatization" and "innovation" in all official provincial ("Daily") newspapers between 2000 and 2013. ${ }^{20}$ In China, the media are strictly controlled by the state. While the central Chinese Communist Party (CCP) has the ultimate control over all newspapers, each provincial government controls the local media and publishes three types of newspapers. The first is the "Daily," which is directly owned by the provincial CCP committee and whose editorial policies are strictly supervised by CCP officials: for example, the "Beijing Daily" and the "Henan Daily" are the official publications of those province-level governments. The second type of newspaper is the

\footnotetext{
${ }^{20}$ Newspaper articles are searched through the CNKI China Core Newspaper Full-Text Database (重要报纸全文数 据库), available at http://epub.cnki.net/kns/brief/result.aspx?dbPrefix=CCND (accessed May 2, 2016). The CNKI database collects articles from 605 newspapers (which account for over $70 \%$ of the total newspaper circulation in China) since 2000 and is updated continuously.
} 
"Evening" publication, which is owned by a CCP committee but enjoys substantially more editorial autonomy than the "Daily." The third type consists of subsidiary newspapers with various names, such as the "Metro," which enjoy further editorial autonomy though they are still controlled by the state. ${ }^{21}$ In this hierarchical and strictly controlled system, a search in the "Daily" papers yields a clear indication of the policy focus at various points of time.

The graph shows two distinct waves of policy focus. Reflecting the historical fact that the privatization wave occurred before the focus on innovation, we see that "privatization" enjoyed a surge in media mentions before 2005 and then subsided. In contrast, there is a surge in the media mentions of "innovation" after 2011. Between 2000 and 2013, we found only 55 articles that mention both key words "privatization" and "innovation," all of which appeared in the years between 2011 and 2013 (as noted above, our SOE privatization sample ends in 2011).

Thus, for the purpose of analyzing innovation, SOE privatizations provide a largely exogenous change to the ownership structure, which allows us to make a causal inference about the relation between ownership type and innovation. If ownership type affects firms' incentives to innovate, then the before-and-after change in innovation as a result of SOE privatizations should be a clean indication of that effect. In addition, if private firms are more sensitive to IPR protection, then the before-and-after change in innovation should be larger for privatizations that occurred in prefectures with stronger IPR protection (i.e., a difference-in-difference approach).

To construct a comprehensive sample of SOE privatizations, we rely on two leading corporate datasets on Chinese firms. The first is CSMAR/WIND, a dataset similar to (and, in fact, fashioned on) the CRSP and COMPUSTAT databases in the U.S. This database covers Chinese publicly listed firms and has been used in studies published in leading journals (Xiong and Yu

\footnotetext{
${ }^{21}$ See Qin, Stromberg, and Wu (2014) and references therein for a more detailed discussion of the organization of the media industry in China.
} 
2011, among others). The second is the Chinese Industrial Enterprises Database, a longitudinal micro-level database compiled by the National Bureau of Statistics of China (NBSC) based on annual surveys of industrial firms (manufacturing, mining, and construction) that have more than five million RMB in annual sales. Similar to the U.S. Census data, this database is the most comprehensive source of information on unlisted firms. ${ }^{22}$ The drawbacks of this database, however, are that due to size requirements, many firms do not have a complete time series, and linking records across years can be problematic. Leading academic papers have used this database to study Chinese firms' productivity (e.g., Hsieh and Klenow 2009; Song, Storesletten, and Zilibotti 2011).

Identifying privatizations among the listed sample from CSMAR is relatively straightforward. Since 2001, Chinese listed firms are required to report their ownership (equity) structure. Following prior literature (e.g., Wang, Wong, and Xia 2008), we define a company as state-owned if its largest ultimate shareholder is a government entity, which can either be the central government (e.g., the Ministry of Finance) or local governments. Otherwise, we define the company as a private enterprise (i.e., if the largest ultimate owner of these firms is either an individual—we aggregate individual investors who are family members—or a private institutional investor). We identify SOE privatizations by comparing changes of ownership status between two consecutive years. On average, government ownership of the listed companies in our sample averaged $43.1 \%$ of firms' equity in the five years before the privatizations; in the five years after, the average went down to $23.0 \%$.

\footnotetext{
${ }^{22}$ The database is called 工业企业数据库 in Chinese, whose direct translation is “Industrial Enterprises Database.” In earlier papers published in leading academic journals, it has been called the "China Industrial Survey" (e.g., Hsieh and Klenow 2009).
} 
To identify privatizations of unlisted companies from the Chinese Industrial Enterprises Database, we first construct complete firm histories from the dataset by matching data from consecutive years. When available, we use a firm's unique permanent ID (known in China as the Legal Person Code $^{23}$ ) to trace the firm over time. But this ID is often missing in the Industrial Enterprises Database as firms sometimes omit this field in their survey reports. In those instances, we follow prior literature and use a combination of five variables to identify firms: company name, sector code, province, city, and address. ${ }^{24}$ Erring on the side of caution, all five variables need to match exactly for us to consider two records to be from the same firm.

We then rely on two data items to identify SOE privatizations of unlisted firms. First, when available, we use the detailed equity ownership information in the "Financial Information" section of the database. Equity ownership is reported by the following owner categories: state, collective, individual, legal persons, ${ }^{25}$ overseas Chinese (Hong Kong/Macau/Taiwan), and other overseas. We classify a firm as a SOE if the equity ownership in the state category exceeds $50 \%$. A firm is considered to have gone through a privatization if in the subsequent year, this ratio (a) falls below $50 \%$ and (b) the equity ownership in another one of the seven categories exceeds that of the state category. Second, when this detailed information is not available, we use the field called "Registration Type" in the "Basic Information" section of the database in which firms identify themselves as one of seven ownership types: SOE, COE (collective-owned enterprises), HMT (Hong Kong, Macau, Taiwan), FOR (foreign owned), SHR (shareholding company) or PRI

\footnotetext{
${ }^{23}$ According to Chinese law, a legal person is an organization that is incorporated in accordance with the law and that has its own assets, name, and address, exercises civil rights and assumes civil legal liabilities on its own, independent of its members. In essence, the notion of a legal person organization is similar to the notion of a limited liability firm in the west. A company's Legal Person Code is the company ID created upon the legal creation and registration of the company and remains unchanged throughout the company's existence.

${ }^{24}$ See Hsieh and Klenow (2009), Song, et al. (2011), and Dougherty et al. (2007) for discussions of the data. Nie, et al. (2012) provides a detailed summary of the potential pitfalls and remedies when using the Chinese Industrial Enterprises Database.

${ }^{25}$ These refer to shares held by other corporate entities.
} 
(privately-owned). We consider a privatization to have occurred if this status changes from SOE to PRI. ${ }^{26}$

Table 2 summarizes our privatization sample by year (before being matched to the IPR data, which - as noted above - covers only 25 provinces). An overwhelming majority of the privatizations occur between 2002 and 2006, consistent with historical accounts. The privatizations are geographically diverse: in the peak years between 2002 and 2006, on average 27 provinces (out of 31) are represented in the sample. This reflects the sweeping nature of China's privatization wave. In all, our sample consists of 1,156 privatization events. ${ }^{27}$ After matching with the IPR score data, the ultimate sample later used in our analyses consists of 898 privatizations spanning 25 provinces. While this is likely to be only a fraction of all the privatizations that took place in China, our sample size is comparable to other large sample studies of SOE privatizations in China. ${ }^{28}$

To further allay the concern that privatization events may be related to systematic changes in key firm attributes, Table 3 compares key firm characteristics in the year before the privatization with the year after. We examine firm size (measured as the logarithm of total assets in RMB), the ratio of intangible assets to total assets, return on assets (calculated as net income divided by total assets), and leverage (calculated as total debt divided by total assets). All ratios are expressed in decimal points. The table reveals no meaningful changes in any of these statistics.

\footnotetext{
${ }^{26}$ Prior work has used a broader definition of SOE privatizations from the Industrial Enterprises Database. Jefferson and Su (2006) and some other authors rely exclusively on the Registration Type variable and classify SEO privatizations as cases where the ownership type changes from SOE to SHR, i.e., shareholding enterprises. Our approach of first using actual shareholding information where available is more precise. Furthermore, even when an SOE becomes a shareholding enterprise, the state can still control a significant (and even a majority) stake and wield strong influence. In our paper, we seek to identify truly significant ownership structure changes, so we use the more stringent classification detailed in the text. Our results are robust to adding the sample identified using the Jefferson and Su (2006) approach. Our results are also robust to using only the privatizations identified from listed firms.

${ }^{27}$ The Industrial Enterprises Database is unavailable after 2009. The small number of privatizations in 2010 and 2011 are taken from the listed sample.

${ }^{28}$ We miss some privatization events because of gaps in the databases and because these databases do not cover all Chinese firms. Our stringent firm identification criteria mean that our sample errs on the conservative side. The sample in Gan, et al. (2008) consists of roughly 900 privatized firms.
} 


\section{Other Data}

In our regression analysis, we use a number of control variables, such as annual provincelevel GDP growth and university density (the number of four-year colleges per 100,000 population). These data come from the Chinese Annual Statistical Yearbooks. ${ }^{29}$ Firm-level control variables come from CSMAR and the Industrial Enterprises Database. See Appendix 1 for a list of our data sources.

\section{Findings}

\section{A. Baseline Results}

We begin by examining the univariate relationship between ownership type and innovation. Table 4 compares the five-year average patent stock before the privatization with the five-year average after. Privatizations are positively related to innovation. Not only are the results statistically significant, but the economic magnitudes are also large: the average patent stock increases from 0.416 before privatization to 1.495 afterwards, an increase of over $250 \%$ $(1.495 / 0.416-1)$

Finding that private firms are more innovative is unsurprising in a Western context, where private ownership and decentralized decision-making are often associated with better management (e.g., Bloom and Van Reenen 2007). But it is noteworthy in the Chinese context. With poor property rights and weak rule of law, it is not clear a priori that private firms would have stronger incentives to innovate than SOEs, as they are ill-protected from expropriation. The fact that even in China private ownership increases innovation suggests the power of incentives.

\footnotetext{
${ }^{29}$ http://www.stats.gov.cn/english/statisticaldata/AnnualData/ (accessed May 2, 2016).
} 
Next, we focus on the central question of this paper: What is the interactive effect of ownership type and IPR protection on innovation? Are private firms more sensitive to IPR protection than SOEs? If so, we should find that the increase in post-privatization innovation is larger in regions with stronger IPR protection than in regions with weaker protection.

Table 5 presents the results of a difference-in-difference analysis where we compare the post-privatization increase in firms' patent stock across prefectures with high and low IPR protection (that is, an IPR score above or below the median score) in the year of the privatization. We report the average patent stock in the five years before and five years after privatization. Panels $\mathrm{A}, \mathrm{B}$, and $\mathrm{C}$ report the results for both invention and utility patents, invention patents alone, and utility patents alone, respectively. All panels reveal a consistent pattern:

- First, firms' patent stock always increases significantly after the privatization, which is consistent with results in Table 4. The ratio of after/before patent stock is generally between 3 and 4, implying an increase of between $200 \%$ and $300 \%$.

- Second, both before and after privatization, the patent stock is higher in high IPR protection regions than in low IPR protection regions. The differences are large economically and statistically. For instance, even before privatization, firms' invention and utility patent stock (Panel A) is over three times higher in high IPR protection regions than in low IPR protection regions ( 0.579 versus 0.177$)$. Firms' invention patent stock (Panel B) is more than four times higher in high IPR protection regions than in low IPR protection regions (0.219 versus 0.047$)$.

- The post-privatization increase in patent stock is significantly larger in high IPR protection regions than in low IPR protection regions. The magnitudes of the differences are large. Invention and utility patent stock (Panel A) more than quadrupled after privatizations in 
regions with high IPR protection (2.474 versus 0.579$)$, and nearly tripled in regions with low IPR protection $(0.528$ versus 0.177$)$. While patent stock growth rates are high across the board, the difference between high and low IPR protection regions is significant.

In Table 6, we estimate panel regressions to control for additional factors that could confound the difference-in-difference analysis. The sample consists of firm-year observations of firms that have undergone a privatization between 2002 and 2011. For each privatization event, we use five years of data before and five years of data after the event. The key regression we estimate is the following:

$$
\begin{aligned}
& \log \left(\text { Patent_Stock }_{i, t}+1\right)=a+b_{1} \text { POST }_{i, t}+b_{2} I P R_{i, t-1}+b_{3} \text { POST }_{i, t} \times I P R_{i, t-1}+ \\
& \text { Controls }_{i, t-1}+\varepsilon_{i t} \quad \text { (4) }
\end{aligned}
$$

The dependent variable is the (natural logarithm) of (one plus) a firm's patent stock in year t. POST is an indicator variable that takes on the value of one for years after privatization and zero otherwise; IPR is the measure of the IPR score in the prefecture where the firm is located in year $t-1$; and POST $\times I P R$ is the interaction between the two variables. Control variables include firm level characteristics measured at the end of year $t-1$ : size (expressed as the logarithm of assets measured in RMB), intangible assets (as a fraction of total assets), return on assets (defined as net income divided by total assets), leverage (defined as total debt divided by total assets), and age (the number of years since the firm's inception). Province-level controls include GDP growth from years $t-1$ to $t$ (in decimals), university density in year $t-1$ (measured as number of four-year universities per 100,000 population), and the increase in government R\&D subsidies (calculated as the change in the amount of government R\&D subsidy from year $t-1$ to $t$ divided by the 
provincial GDP in year $t-1) .{ }^{30}$ We also include industry and province fixed effects. In one specification, we also include firm fixed effects. Standard errors are clustered by province.

The results in Table 6 are consistent with those in Tables 4 and 5. In model (1), both the $P O S T$ and the IPR variable are positive and significant, indicating that better IPR protection and private ownership are both positively associated with innovation. In models (2) through (4), the key variable of interest — the interaction term between the POST and IPR protection measures—is positive and significant, indicating that the post-privatization increase in innovation is larger when local IPR protection is stronger. The magnitude is large. For instance, at the mean IPR value of 0.65 between 2002 and 2006 (the peak of the privatization wave), the coefficients of the POST dummy and the POST $\times$ IPR interaction term in model (2) indicate that the average postprivatization increase in patent stock is just $0.01(-0.138+0.225 * 0.65)$. With a one standarddeviation increase in IPR score (0.179), however, the post-privatization effect quadruples to 0.048 $(-0.138+0.225 *(0.65+0.179))$. Thus, the effect of privatization on innovation depends significantly on the extent of local IPR protection.

This conclusion is clearly illustrated by the results in model (3), where we use a dummy variable for IPR protection that equals 1 if a firm is located in a high IPR protection region and zero otherwise. In this specification, we see that the coefficient on the POST indicator alone is negative but insignificant. This means that in low IPR protection regions, privatization per se does not lead to higher innovation. The sign on the POST*IPR dummy interaction is significantly positive, indicating that there is a larger post-privatization gain in innovation from firms located in high IPR protection regions. The average effect of firms in high IPR protection regions is calculated as the sum of the two coefficients: $-0.027+0.071=0.044$. Thus, all else being equal,

\footnotetext{
${ }^{30}$ The Chinese government routinely subsidizes R\&D efforts in local firms, a legacy of the centrally planned economy; hence, we control for government spending on R\&D by including this variable.
} 
the post-privatization effect goes from a negative 0.027 to a positive 0.044 as the firm moves from a low to a high IPR protection region. In other words, all the post-privatization gains in innovation are concentrated in regions with high IPR protection standards. In model (6), we include firm fixed effects to further control for unobserved firm-level attributes. With the inclusion of firm fixed effects, the $\mathrm{R}^{2}$ increases to $86.5 \%$. The coefficients suggest an even larger role for IPR protection in modulating privatization's effect on innovation: a one standard-deviation increase in the IPR score increases the post-privatization effect from $0.02\left(-0.192+0.327^{*} 0.65\right)$ to $0.07(-0.192+$ $0.327 *(0.65+0.179))$.

Overall, the results in this section are consistent with the Schumpeterian view: within China, both private ownership and IPR protection are conducive to innovation. Importantly, the effect of privatization on innovation is highly influenced by local IPR protection; privatization has essentially no effect on innovation when IPR protection is weak, and a moderate increase in IPR protection can lead to large gains in post-privatization innovation. This is strong evidence that private sector innovation in China is particularly sensitive to IPR protection.

\section{B. Analysis with Matched Samples}

While the difference-in-difference approach allows for a clean identification of the beforeand-after changes of innovation, it still has limitations. These stem from the assumption that prior to privatizations, firms in high and low IPR protection regions follow similar trajectories in patenting and that after privatizations, the difference in the rates of patenting is caused by the quality of IPR protection rather than pre-existing differences in firms' innovative capacity. If there are systematic differences in firms’ pre-existing innovative capacity between regions with high 
and low IPR protection standards, then it will be difficult to make a causal inference regarding the effect of IPR protection.

To address this concern, we refine the difference-in-difference approach by conducting a matched-sample analysis. Specifically, for every privatization that occurs in a high IPR protection region (the “treatment” firm), we use a propensity score matching algorithm to identify a matching privatization in a low IPR protection region that occurs in the same year (the "matching" firm). The "matching" firm is selected as to have the closest distance in firm characteristics to the “treatment” firm. The firm characteristics we consider are pre-privatization patent stock growth rate, plus the four firm attributes in the year before the privatization that we studied in Table 3: size, intangibles, return on assets, and leverage. We match firms on pre-privatization patent stock growth (calculated as the average annual patent stock growth rate from five years before privatization to one year before privatization) to ensure that the "treatment” and “control” samples follow a parallel trend before being privatized. If a firm from the "control” group is matched to more than one "treatment" firm, we retain the pair for which the distance between the two firms' propensity scores is smallest and discard the other matches. We end up with 380 unique pairs of matched firms.

After creating the "treatment” and “control” sample in this way, we repeat the univariate difference-in-difference analysis (as in Table 5) and the regression analysis (similar to Table 6). Our sample consists of observations from five years before the privatization to five years after. Because the matched sample already controls for firm characteristics, we use the following regression specification to focus on time-series dimension of the difference-in-difference:

$$
\begin{aligned}
& \log (\text { Patent Stock }+1)=a+b_{1} \text { TREAT } \times \text { BEFORE } E^{-2 \&-1}+b_{2} \text { TREAT } \times \text { CURRENT }+b_{3} \text { TREAT } \times \\
& \text { AFTER }^{1}++b_{4} \text { TREAT } \times A F T E R^{2+}+b_{5} \text { BEFORE } \\
& +b_{8} \text { AFTER }^{2+}+\varepsilon_{i t}
\end{aligned}
$$


The dependent variable is the (natural logarithm) of (one plus) a firm's patent stock in year t. The variable TREAT is a dummy that equals one for the treatment firms (firms located in high IPP regions), and zero for control firms (firms located in low IPP regions). BEFORE ${ }^{-2 \&-1}$ is a dummy that equals one if a firm-year observation is from two or one year(s) before the privatization (year -2 and -1 ,) and zero otherwise. CURRENT is a dummy that equals one if a firm-year observation is from the privatization year (year 0 ), and zero otherwise. AFTER $^{1}$ is a dummy that equals one if a firm-year observation is from the year immediately after the privatization (year 1), and zero otherwise. AFTER ${ }^{2+}$ is a dummy that equals one if a firm-year observation is from the second year after privatization until the end of the window, and zero otherwise.

Results using the matched sample are reported in Table 7. Panel A checks the validity of our matching procedure and shows that the "treatment" and the "control" samples are very similar along all four characteristics we examine. The differences in pre-privatization patent stock and other firm characteristics are not only statistically insignificant, but also small in magnitude. Panel B reports the univariate difference-in-difference analysis. Results in this panel are qualitatively similar to those in Table 5: The post-privatization increase in patenting rates for firms in high IPR protection regions are at least two to three times higher than the increase for firms in low IPR protection regression. Finally, the regression results in Panel C not only confirm the same conclusions, but also provide additional insights into the timing of firms' ramping up of innovative activities: Significant differences in innovation between firms in high and low IPR protection regions manifest themselves two years after privatizations.

Figure 5 visually illustrates the different innovation trajectories followed by the "treatment" and the "control" samples. The figure shows that, prior to privatization (time $=0$ ), the two sets of firms are on a parallel trend in terms of innovation. This means that the crucial assumption of no 
pre-existing differences is met. After privatization, the two sets of firms exhibit a diverging trend in their patent stock. Newly privatized firms located in regions with high IPR protection significantly outperform newly privatized firms located in regions with low IPR protection.

\section{Instrumental Variables Regression}

In our empirical design, we use a survey-based IPR protection measure to capture directly the perceived quality of local IPR protection. While this survey-based measure alleviates reverse causality concerns that some other measures face, it is not ironclad.

To address these concerns, in this section we use instrumental variable (IV) regressions to provide a further check on the robustness of our results. We borrow from Ang, Cheng, and Wu (2014) and use two province-level instruments for IPR protection. The first is the number of Christian colleges founded by missionaries in a province by 1920 (Stauffer, Wong, and Tewksbury 1922). Christian colleges were important in instilling Western values such as the respect for private property among the Chinese people. ${ }^{31}$ The second instrument is British settlement, an indicator variable that equals one if a province had a British concession during the Qing dynasty. The British, along with other colonial powers, established the local administrative and legal systems according to their own values. British settlements would thus be instrumental in spreading common-law values such as property rights. ${ }^{32}$ Thus, these two variables should be correlated with provincial IPR protection, as they measure the provinces' historical exposure to the idea of property rights. At the same time, they should primarily affect current day innovation through IPR protection, once

\footnotetext{
${ }^{31}$ Well-known Christian colleges include, for example, St John's University, which was founded by the American Episcopal Church, and Soochow University, founded by American Methodist missionaries.

${ }^{32}$ The British concessions (or leased territories) included Xiamen city in Fujian, Hankou city in Hubei, Jiujiang City in Jiangxi, Zhenjiang City in Jiangsu, Guangzhou City in Guangdong, Weihaiwei in Shandong, Tianjin, and Shanghai (Yang and Ye 1993).
} 
other regional factors that could affect innovation have also been controlled for. Although it is possible for these historical events to affect current-day innovations in other ways, this is unlikely after controlling for other factors.

Table 8 reports both the first and second stage results from the IV regression. In the first stage, we use the two instrumental variables - Christian College (the number of colleges founded by Christian missionaries in a province before 1920) and British Settlement (a dummy variable that equals one if the province had a British concession in the Qing Dynasty and zero otherwise) - and other province level variables to predict IPR protection score. The results show that both instruments are highly significant in predicting IPR protection. The F-test for instrument strength is highly significant (an F-statistic of 143.84, with a p-value of 0.000), indicating the two instruments are strong.

In the second stage, the unit of observation is (as in Table 6) annual observations of each privatized firm for the five years before and the five years after the privatization. The dependent and independent variables are identical to those in regressions (1) through (3) of Table 6, except that here we employ the instrumented value of the IPR protection measure.

Consistent with Table 6, the key interaction term between POST and the instrumented IPR has a positive sign, meaning that local IPR protection significantly moderates the effect of privatization on innovation: strong IPR protection makes privatizations more conducive to innovation. The magnitudes are in line with the baseline. The mean instrumented value of IPR score is 0.65 , and its standard deviation is 0.067 . Therefore, based on model (1) estimates, the mean post-privatization change in innovation is essentially $0(-0.34+0.523 * 0.65)$. With a one standard-deviation increase in the (instrumented) IPR score, the effect increases to 0.035 ($0.34+0.523 *(0.65+0.067))$. These estimates suggest that the post-privatization gains in innovation 
are concentrated in regions with above average IPR protection; in regions with low IPR protection, the gain is negligible. Finally, the Sargan-Hansen test for over-identifying restrictions does not reject the null hypothesis that the residuals are uncorrelated instruments. Overall the IV regression analysis in this section confirms our baseline finding.

\section{Patent Quality}

The analysis so far focuses on the quantity of patents, but this is hardly the only important measure of innovation. Since the pioneering work of Griliches (1990), it has been widely recognized that patent quality varies significantly. Even though privatized firms generate more patents, this proliferation may not represent a boost to innovation if they are filing trivial patents. Private business owners may be more likely to file for trivial patents to "game the system," for instance, in the hopes of impressing prospective investors, or in the Chinese context, being classified as "high tech" and gaining a government subsidy. Thus, it is important to assess the quality of the patents.

To do so, we collected the global patent application and citation data for the 331 firms publicly listed firms in China with the most Chinese patents. ${ }^{33}$ Of these 331 firms, 162 are SOEs (49\%) and 169 (51\%) private enterprises. We look at data across multiple patent offices rather than just using U.S. filings, because a relatively modest share of Chinese firms’ patents have been filed in the U.S. To analyze these, we use data from Patent Sight GmbH, which has compiled a rich array of information on global patent families (a patent family includes all versions of a given patent filed in different national or regional patent offices). These data allow us to compare patent quality across firm types and over time. Firms are classified as SOEs or private firms based on

\footnotetext{
33 Due to the rarity of international patents among unlisted Chinese firms, the analysis in this section pertains to listed firms and also deviates from the difference-in-difference approach.
} 
their status in the year of the first publication of the patent (which typically occurs 18 months after filing) according to the methodology described above.

We concentrate on a number of key measures:

- "Citations received per patent" is the number of citations received worldwide per patent family owned by each firm as of year-end 2014. This is akin to the typical measure of importance, as explored in Jaffe and Trajtenberg (2005) and many subsequent works.

- “IPC groups per patent” is the mean number of IPC groups that each patent family has been assigned to (a proxy for patent scope, as in Lerner 1994).

- “\% patents active in the U.S./Japan/European Patent Offices (EPO)” is the fraction of a firm's patent families awarded through that date that have patents that are pending and/or are granted in the respective patent offices as of year-end 2014. “\% patent active in WIPO” is the share of the firm's patents active under the Patent Cooperation Treaty as of year-end 2014. ${ }^{34}$ Again, the extent of patent families has been used as a proxy for patent importance by Lanjouw, Pakes, and Putnam 1998 and subsequent authors.

We examine these patterns using all patents (in Panel A), those first published between the beginning of 1990 and the end of 2005 (Panel B), and those first published between 2006 and 2014 (Panel C).

Table 9 shows the results. When we examine the overall sample, we see that private firms' patents, far from being of lower quality, actually have significantly more citations and fall into more four-digit IPC groups (a proxy for broader scope). Moreover, they are significantly more likely to be still active in the U.S. and at the WIPO. The results regarding citations and patents

\footnotetext{
${ }^{34}$ The World Intellectual Property Organization (WIPO) administers the Patent Cooperation Treaty, which provides a streamlined way for firms to apply for patent protection in multiple patent offices. Applicants need not use the WIPO and can file directly with the national patent offices, but going through WIPO provides a number of advantages.
} 
active in the U.S. are statistically significant in both time periods examined; the remaining results are only present in the 2006-2014 period. (The result regarding the greater tendency of SOE patents in the later period to be active in Japan is harder to explain.) In short, the results are inconsistent with the notion that the growth of private firm patenting is due to a proliferation of low-quality awards: if anything, the opposite pattern is at work.

\section{Conclusion}

In this paper, we study how intellectual property right protection affects innovation in China in the years around the privatizations of state-owned enterprises. Focusing on SOE privatizations allows us to use a difference-in-difference approach to identify the causal impact of ownership type (state-owned versus private) and IPR protection on innovation.

Consistent with the Schumpeterian view of the role of institutions, we find two main results. First, within China, privatizations are associated with an increase in innovation. Firms' mean patent stocks are $200 \%-300 \%$ larger in the five years after privatizations, compared to the five years before. Second, local IPR protection is a significant moderator of this relationship: A one standard-deviation increase in local IPR protection score almost quadruples the post-privatization increase in patent stock. In fact, nearly all the post-privatization increase in patenting is achieved by firms in regions with high IPR protection standards.

Our results contribute to the literature in two ways. First, these results address the "China puzzle": the perception that China is an outlier in the law and finance framework. Our singlecountry focus and unique identification technique suggest a more normal relationship between institutions and economic outcomes, one that is more consistent with the Schumpeterian views on institutions and growth. 
Our second contribution is the policy implications of our results. Innovation today is a matter of first-order importance to China and its leaders. In order to successfully transition the country from a development model that is dependent on cheap labor and physical investments to one that is innovation-driven, our results suggest that the role of the private sector will be crucial, as private firms are more innovative both in terms of quantity and quality of patents. For innovation in the private sector, legal institutions appear critical. 


\section{References}

Aghion, P., Cai, J., Dewatripont, M., Du, L., Harrison, A., and Legros, P. 2015. “Industrial policy and competition.” American Economic Journal: Macroeconomics 7: 1-32.

Allen, F., Qian, J., and Qian, M. 2005. “Law, finance, and economic growth in China.” Journal of Financial Economics 77: 57-116.

Ang, J., Cheng, Y., and Wu, C. 2014. "Does enforcement of intellectual property rights matter in China? Evidence from financing and investment choices in the high tech industry." Review of Economics and Statistics 96: 332-348.

Arrow, K. 1962. "Economic welfare and the allocation of resources for invention.” In The Rate and Discretion of Inventive Activity, edited by R. Nelson. Princeton, NJ: Princeton University Press.

Bloom, N., and Van Reenen, J. 2007. "Measuring and explaining management practices across firms and countries.” Quarterly Journal of Economics 122: 1351-1408.

Cohen, L., Gurun, U., and Kominers, S. 2016. “Patent trolls: Evidence from targeted firms.” Harvard Business School working paper.

Dougherty, S., Herd, R., and He, P. 2007. "Has a private sector emerged in China’s industry? Evidence from a quarter of a million Chinese firms.” China Economic Review 18: 309-334.

Fan, J., Wong, T., and Zhang, T. 2013 "Institutions and organizational structure: The case of state-owned corporate pyramids.” Journal of Law, Economics, and Organization 29: 1217-1252.

Gan, J. 2009. “Privatization in China: Experiences and lessons.” In China’s Emerging Financial Markets: Challenges and Opportunities, edited by J. Barth, J. Tatom, and G. Yago. New York: Springer.

Gan, J., Guo, Y., and Xu, C. 2008. “A nationwide survey of privatized firms in China.” Unpublished working paper.

Griliches, Z. 1990. "Patent statistics as economic indicators: A survey.” Journal of Economic Literature 28: 1661-1707.

Griliches, Z., ed. 1984. R\&D, Patents and Productivity. Chicago: University of Chicago Press for the National Bureau of Economic Research.

Hall, B. H. 1993. “The stock market's valuation of R\&D investment in the 1980s.” American Economic Review 83: 259-264.

Hall, B. H., Jaffe, A., and Trajtenberg, M. 2005. "Market value and patent citations.” RAND Journal of Economics 36: 16-38.

Hsieh, C. and Klenow, P. 2009. "Misallocation and manufacturing TFP in China and India.” Quarterly Journal of Economics 124: 1403-1448. 
Hsu, P., Wang, C., and Wu, C. 2013. "Banking systems, innovations, intellectual property protections, and financial markets: Evidence from China.” Journal of Business Research 66: 2390-2396.

Jaffe, A., and Lerner, J. 2004. Innovation and its Discontents. Princeton: Princeton University Press.

Jaffe, A., and Trajtenberg, M. 2005. Patents, Citations, and Innovations: A Window on the Knowledge Economy. Cambridge: MIT Press.

Jefferson, G., and Su, J. 2006. "Privatization and restructuring in China: Evidence from shareholding ownership, 1995-2001.” Journal of Comparative Economics 34: 146-166.

Keller, W. 2002. “Geographic localization of international technology diffusion.” American Economic Review 92: 120-142.

King, R., and Levine, R. 1993. "Finance and growth: Schumpeter might be right.” Quarterly Journal of Economics 108: 717-738.

La Porta, R., Lopez-de-Silanes, F., Shleifer, A., and Vishny, R. 1998. "Law and finance.” Journal of Political Economy 106: 1113-1155.

Lanjouw, J., Pakes, A., and Putnam, J. 1998. "How to count patents and value intellectual property: The uses of patent renewal and application data.” Journal of Industrial Economics 46: 405-432.

Lerner, J. 1994. "The importance of patent scope: An empirical analysis.” RAND Journal of Economics 25: 319-333.

Nelson, R. 1959. “The simple economics of basic scientific research.” Journal of Political Economy 67: 297-306.

Nie, H., Jiang, T., and Yang, R. 2012. “A review and reflection on the use and abuse of Chinese Industrial Enterprises Database.” (Chinese) World Economy 5: 142-158.

Priest, G., and Klein, B. 1984. “The selection of disputes for litigation.” Journal of Legal Studies 13: 155.

Qin, B., Stromberg, D., and Wu, Y. 2014. “The determinants of media bias in China.” Unpublished working paper.

Rajan, R. and Zingales, L. 1998. "Financial dependence and growth.” American Economic Review 88: 559-586.

“The rise of state capitalism.” The Economist, Last modified January 21, 2012.

Schumpeter, J. 1934. The Theory of Economic Development: An inquiry into profits, capital, credit, interest and the Business Cycle. Cambridge, MA: Harvard University Press. 
Snyder, N. 2012. "Putting numbers to feelings: Intellectual property rights enforcement by Chinese courts-Evidence from Zhejiang trademark infringements, 2004-2009.” Northwestern Journal of Technology and Intellectual Property 10: 349-376.

Song, Z, Storesletten, K., and Zilibotti, F. 2011. “Growing like China.” American Economic Review 101: 202-241.

Stauffer, M., Wong, C., and Tewksbury, M., ed. 1922. The Christian Occupation of China: A General Survey of the Numerical Strength and Geographical Distribution of the Christian Forces in China. Shanghai: China Continuation Committee Press.

Wang, Q., Wong, T., and Xia, L. 2008. "State ownership, the institutional environment, and auditor choice: Evidence from China.” Journal of Accounting and Economics 46: 112-134.

Williams, H. 2013. "Intellectual property protection and innovation: Evidence from the human genome." Journal of Political Economy 121: 1-27.

Xiong, W., and Yu, J. 2011. “The Chinese warrants bubble.” American Economic Review 101: 2723-2753.

Yang, Z. and Ye, F. 1993. Studies on Semi-Colonization of Qing Dynasty. Beijing: Higher Education Press. 


\section{Figure 1. Intellectual Property Protection in China: Geographic Variation}

This map depicts the regional variation in IPR protection across mainland Chinese provinces. The IPR protection data are from 2002-2011 and are at the prefecture-year level. We calculate province-level results using averages of prefectures within each province every year, and then calculate and graph the time-series averages of each province.

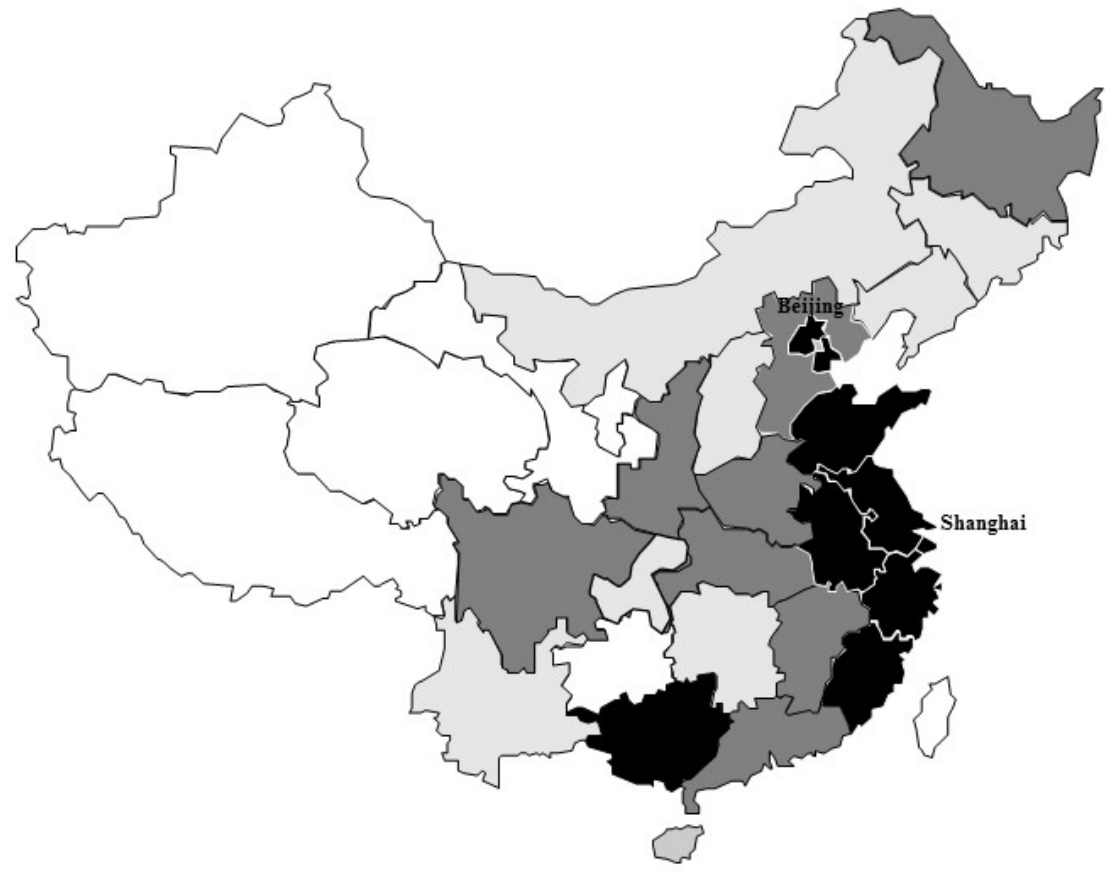




\section{Figure 2. IPR Score Over Time}

This figure plots the mean IPR scores across prefectures over time. The IPR score data are from the Chinese Academy of Social Sciences and its calculation is detailed in the text. Prefectures in the high (low) IPR group are those whose IPR scores are above (below) the median each year.

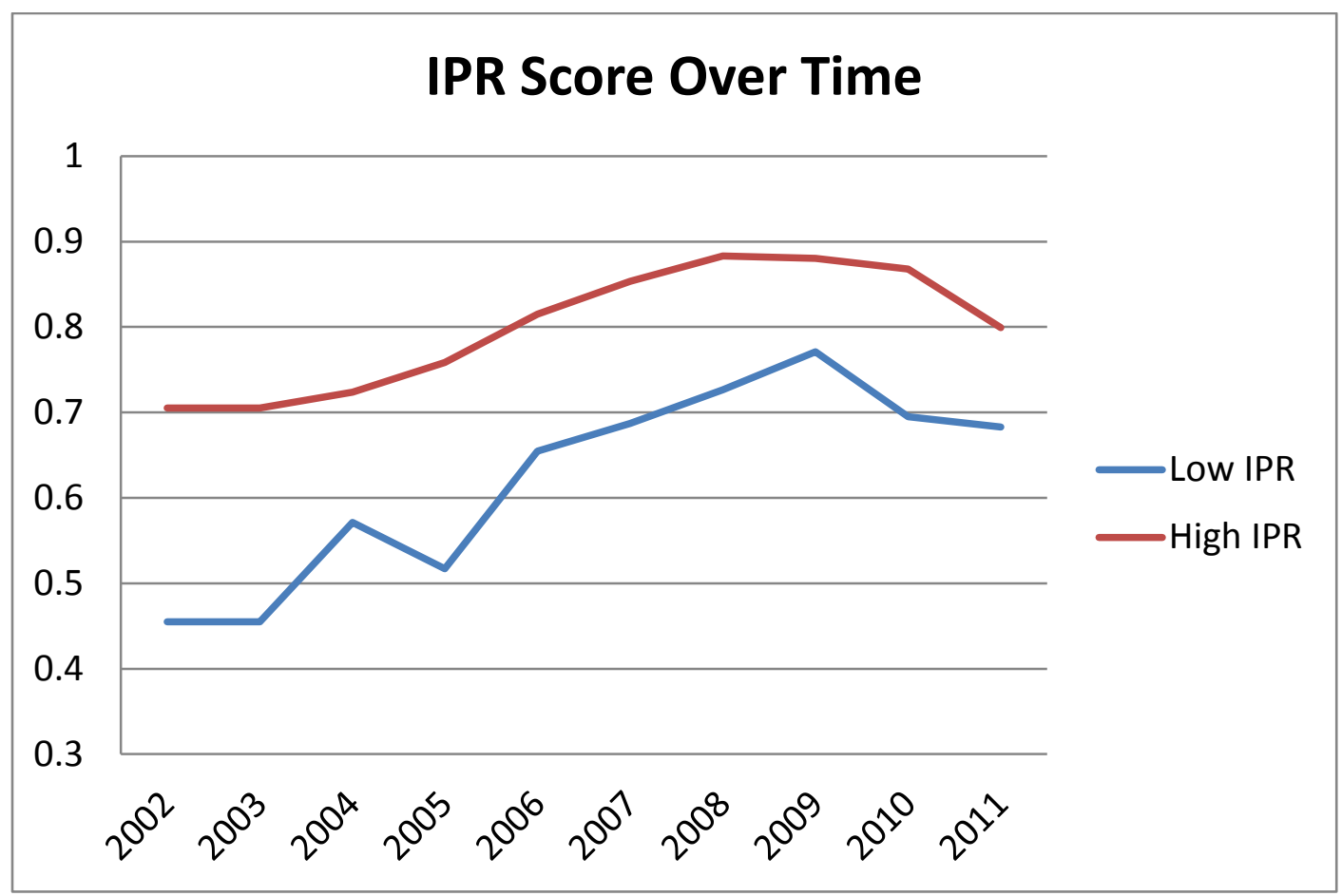




\section{Figure 3. Innovation Trend}

This figure plots the patent stock over time for privately owned firms and state-owned enterprises (SOEs). Patent data are from the Chinese State Intellectual Property Office. Patent stock is calculated as in Equation (3) and scaled by million RMB in assets.

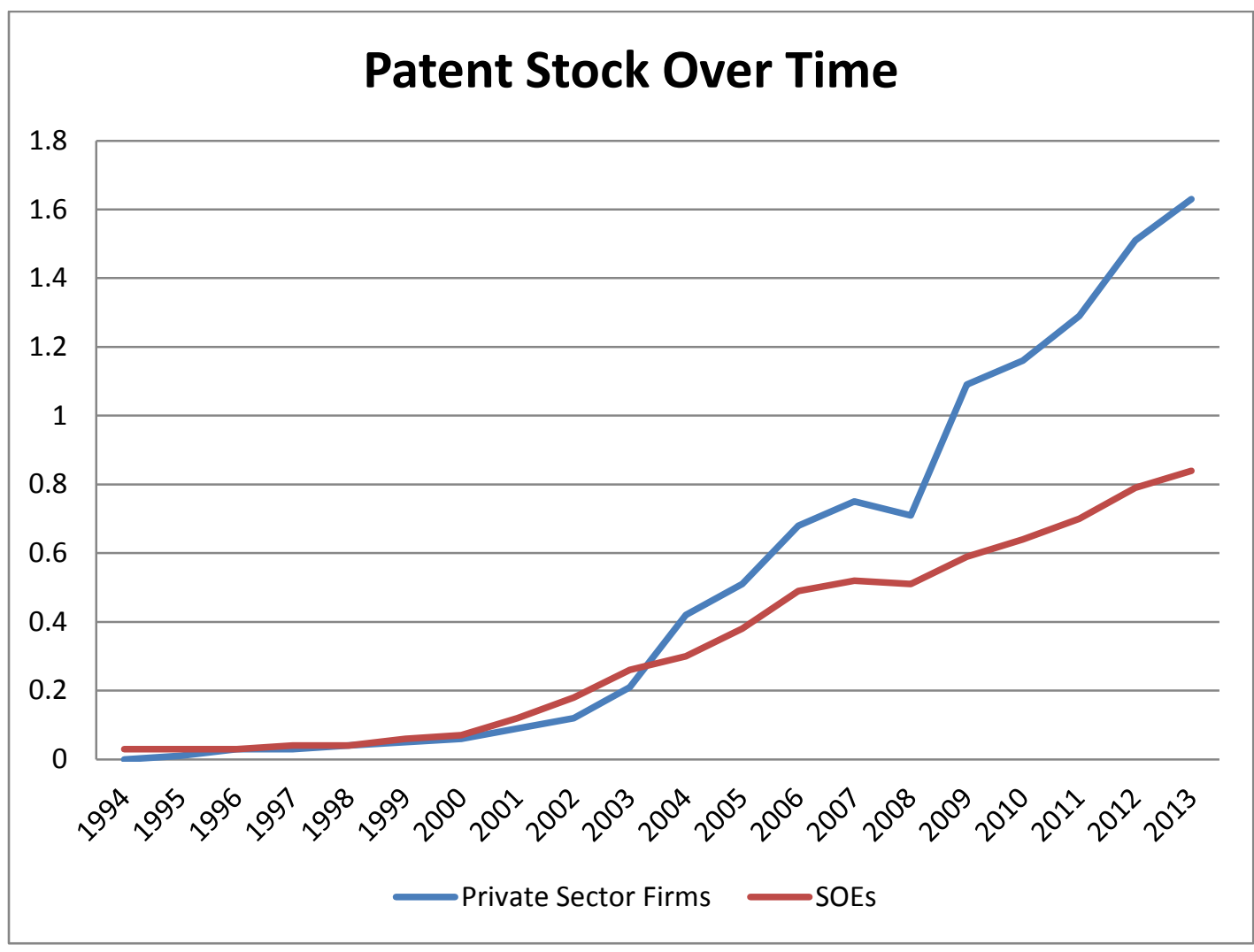




\section{Figure 4. Policy Trends: Privatization vs. Innovation}

This figure plots the frequency of media mentions of the keywords "Innovation" and "Privatization" in all the "Daily" newspapers - the official publications of provincial governments in China. The numbers are calculated by dividing the number of articles that contain each keyword with the number of total articles in a given year, averaged across all provinces.

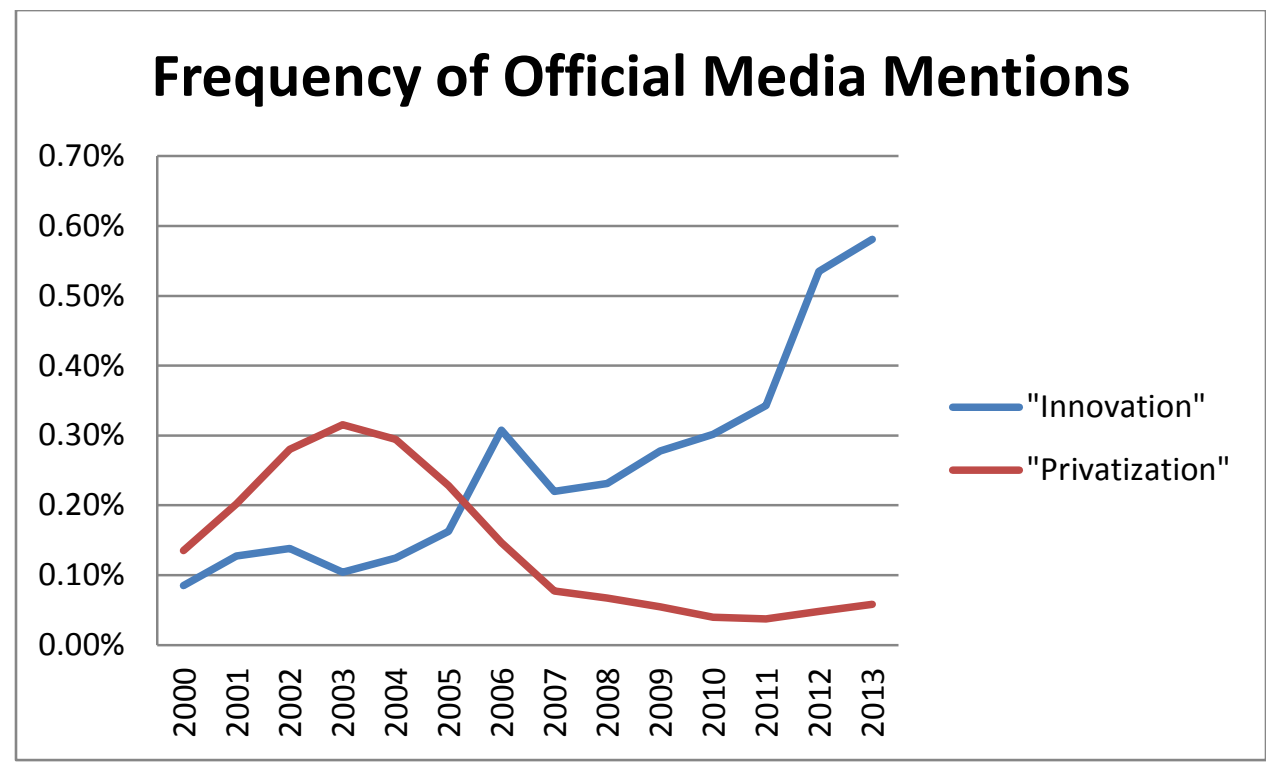




\section{Figure 5. Privatizations and Innovation: Matched Sample Analysis}

This figure shows the mean patent stock for treatment and control firms, from five years before the privatization to five year after the privatization. The privatization year is denoted as year 0 . The sample comprises 380 treatment firms (firms located in high IPP protection regions) and 380 unique control firms (firms located in low IPP protection regions) based on the propensity score matching procedures described in Section II.B.

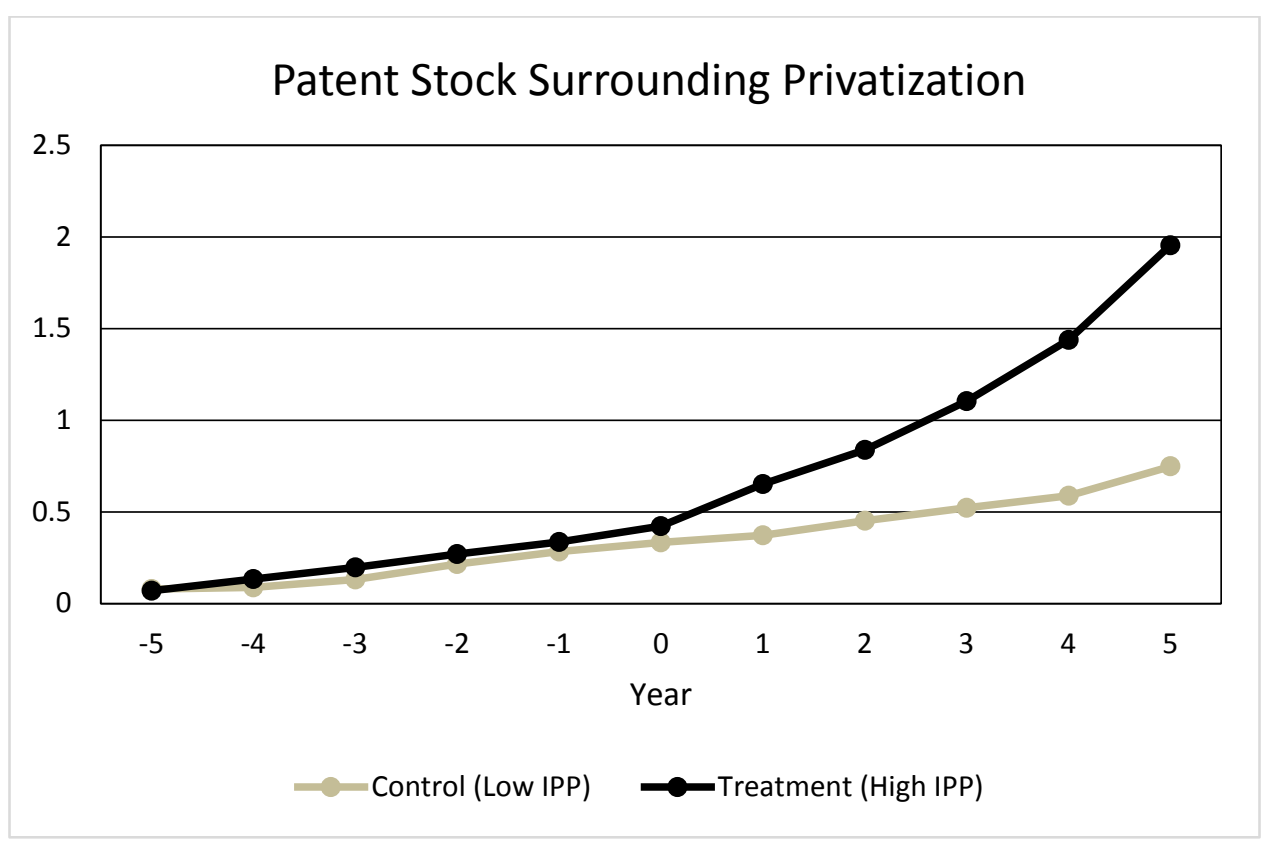




\section{Table 1. Summary Statistics on IPR Protection Index}

This table reports summary statistics of IPR scores provided by the Chinese Academy of Social Sciences. The calculation of the IPR score is detailed in the text. The data are from 2002-2011 and are at the prefecture-year level. We calculate and report provincial-level statistics based on prefectures and years pertaining to each province. The provinces are listed in ascending order of the average IPR score.

\begin{tabular}{|c|c|c|c|c|c|c|}
\hline & \multirow[b]{2}{*}{ Province } & \multirow[b]{2}{*}{$\begin{array}{l}\text { Coastal } \\
(\mathrm{Y} / \mathrm{N})\end{array}$} & \multirow[b]{2}{*}{$\begin{array}{l}\text { Average IPR } \\
\text { Score }\end{array}$} & \multicolumn{3}{|c|}{ Within Province Variation } \\
\hline & & & & Max. & Min. & Std. Dev. \\
\hline 1 & Heilongjing & $\mathrm{N}$ & 0.58 & 0.81 & 0.42 & 0.13 \\
\hline 2 & Yunnan & $\mathrm{N}$ & 0.59 & 0.84 & 0.33 & 0.17 \\
\hline 3 & Jilin & $\mathrm{N}$ & 0.62 & 0.81 & 0.33 & 0.20 \\
\hline 4 & Inner Mongolia & $\mathrm{N}$ & 0.63 & 0.80 & 0.38 & 0.10 \\
\hline 5 & Shaanxi * & $\mathrm{N}$ & 0.64 & 0.77 & 0.48 & 0.09 \\
\hline 6 & Chongqing & $\mathrm{N}$ & 0.64 & 0.72 & 0.50 & 0.08 \\
\hline 7 & Hunan & $\mathrm{N}$ & 0.64 & 0.82 & 0.48 & 0.13 \\
\hline 8 & Liaoning & $\mathrm{Y}$ & 0.65 & 0.82 & 0.42 & 0.12 \\
\hline 9 & Henan & $\mathrm{N}$ & 0.65 & 0.87 & 0.56 & 0.09 \\
\hline 10 & Hubei & $\mathrm{N}$ & 0.66 & 0.90 & 0.42 & 0.16 \\
\hline 11 & Jiangxi & $\mathrm{N}$ & 0.66 & 0.86 & 0.50 & 0.12 \\
\hline 12 & Shanxi * & $\mathrm{N}$ & 0.67 & 0.77 & 0.48 & 0.09 \\
\hline 13 & Sichuan & $\mathrm{N}$ & 0.67 & 0.80 & 0.58 & 0.08 \\
\hline 14 & Hainan & $\mathrm{Y}$ & 0.68 & 0.85 & 0.38 & 0.10 \\
\hline 15 & Guangdong & $\mathrm{Y}$ & 0.70 & 0.96 & 0.25 & 0.17 \\
\hline 16 & Guangxi & $\mathrm{Y}$ & 0.71 & 0.86 & 0.61 & 0.07 \\
\hline 17 & Beijing & $\mathrm{N}$ & 0.71 & 1.00 & 0.55 & 0.14 \\
\hline 18 & Hebei & $\mathrm{Y}$ & 0.72 & 0.87 & 0.58 & 0.08 \\
\hline 19 & Anhui & $\mathrm{N}$ & 0.72 & 1.00 & 0.53 & 0.08 \\
\hline 20 & Fujian & $\mathrm{Y}$ & 0.72 & 1.00 & 0.48 & 0.10 \\
\hline 21 & Tianjin & $\mathrm{Y}$ & 0.74 & 0.87 & 0.58 & 0.09 \\
\hline 22 & Shandong & $\mathrm{Y}$ & 0.75 & 0.95 & 0.50 & 0.09 \\
\hline 23 & Zhejiang & $\mathrm{Y}$ & 0.76 & 1.00 & 0.50 & 0.09 \\
\hline 24 & Jiangsu & $\mathrm{Y}$ & 0.76 & 1.00 & 0.42 & 0.12 \\
\hline 25 & Shanghai & $\mathrm{Y}$ & 0.83 & 1.00 & 0.69 & 0.09 \\
\hline
\end{tabular}

*: Shaanxi is for 山西 in Chinese. Shanxi is for 陕西 in Chinese. These two Chinese provinces have the same phonetic spelling (Chinese pinyin) but with different intonations. We adopted a slightly different spelling to make the distinction. 


\section{Table 2. The Privatization Sample}

This table lists the basic information for our privatization sample. SOE privatizations are identified from the CSMAR database for listed firms and from the Industrial Enterprises Database from the National Statistical Bureau of China (NSBC) for unlisted firms. Details of the identification are discussed in Section I.C.

\begin{tabular}{cccc} 
Year & $\begin{array}{c}\text { Number of } \\
\text { Privatizations }\end{array}$ & Number of Cities & Number of Provinces \\
\hline 2000 & 175 & 103 & 27 \\
2001 & 199 & 109 & 27 \\
2002 & 110 & 70 & 25 \\
2003 & 141 & 89 & 26 \\
2004 & 242 & 136 & 29 \\
2005 & 166 & 97 & 26 \\
2006 & 232 & 133 & 29 \\
2007 & 25 & 22 & 14 \\
2008 & 10 & 10 & 7 \\
2009 & 7 & 6 & 5 \\
2010 & 6 & 5 & 5 \\
2011 & 18 & 17 & 12 \\
\hline
\end{tabular}




\section{Table 3. Firm Characteristics Before and After Privatization}

This table compares firm characteristics in the year before and the year after the privatization. Ln(Assets) is the natural logarithm of total assets (measured in RMB). Intangible is the firm's intangible assets divided by total assets. ROA is the net income divided by total assets. Leverage is total debt divided by total assets. All ratios are expressed in decimal points. T-statistics based on 2-tailed tests are reported (none are statistically significant at conventional confidence thresholds).

\begin{tabular}{lcccc} 
& Before & After & Diff. & t-stat \\
\hline Ln(Assets) & 17.831 & 18.036 & 0.206 & 0.010 \\
Intangible & 0.009 & 0.010 & 0.001 & 0.093 \\
ROA & 0.030 & 0.044 & 0.014 & 0.003 \\
Leverage & 0.655 & 0.653 & -0.002 & -0.860 \\
\hline
\end{tabular}




\section{Table 4. Ownership Type, IPR Protection, and Innovation - Univariate Tabulations}

This table compares firms' patenting rates before and after privatizations. The numbers tabulated are the average patent stock in the five years before and five years after the privatization. *, **, *** denote statistical significance at the $10 \%, 5 \%$, and $1 \%$ levels, respectively.

\begin{tabular}{lcccc}
\hline & Before Privatization & After Privatization & Difference & t-stat (Diff) \\
\hline Invention and utility & 0.416 & 1.495 & 1.079 & $4.793^{* * *}$ \\
patent stock & 0.147 & 0.461 & 0.314 & $3.338^{* * *}$ \\
Invention patent stock & 0.268 & 1.034 & 0.765 & $4.402^{* * *}$ \\
Utility patent stock & & & \\
\hline
\end{tabular}




\section{Table 5. The Interactive Effect of Ownership and IPR Protection: Difference-in-Difference}

This table reports the results of a difference-in-difference analysis where we compare the increase in patent stock before and after privatizations in prefectures with high and low IPR protection. The numbers tabulated are the average patent stock in the five years before and five years after privatization. High (low) IPR protection is based on whether a prefecture's IPR score is above (below) the median score in the year of a privatization event.*, **, *** indicate statistical significance at the $10 \%, 5 \%$, and $1 \%$ levels, respectively.

Panel A: Invention and Utility Patent Stock

\begin{tabular}{lcccc}
\hline & High IPR Protection & Low IPR Protection & Diff (High-Low) & Diff-In-Diff \\
\cline { 2 - 5 } Before & 0.579 & 0.177 & $0.402^{* * *}$ & \\
After & 2.474 & 0.528 & $1.946^{* * *}$ & \\
\hline After - Before & $1.896^{* * *}$ & $0.351^{* * *}$ & & $1.545^{* * *}$ \\
\hline
\end{tabular}

Panel B: Invention Patent Stock

\begin{tabular}{lcccc}
\hline & High IPR Protection & Low IPR Protection & Diff (High-Low) & Diff-In-Diff \\
\cline { 2 - 5 } Before & 0.219 & 0.047 & $0.172^{* *}$ & \\
After & 0.801 & 0.137 & $0.664^{* * *}$ & \\
\hline After - Before & $0.582^{* * *}$ & $0.089^{* *}$ & & $0.492^{* * *}$ \\
\hline
\end{tabular}

Panel C: Utility Patent Stock

\begin{tabular}{lcccc}
\hline & High IPR Protection & Low IPR Protection & Diff (High-Low) & Diff-In-Diff \\
\cline { 2 - 5 } Before & 0.360 & 0.130 & $0.230^{* * *}$ & \\
After & 1.674 & 0.392 & $1.282^{* * *}$ & \\
\hline After - Before & $1.314^{* * *}$ & $0.262^{* * *}$ & & $1.052^{* * *}$ \\
\hline
\end{tabular}




\section{Table 6. Ownership Type, IPR Protection, and Innovation - Regression Analysis}

This table examines the relation between ownership type, IPR protection, and innovation in a panel regression. The sample consists of firm-year observations of firms that have undergone a privatization between 2000 and 2011 . For each privatization event, we use five years of data before and five years of data after the event as observations. The key regression we estimate is:

$\log \left(\right.$ Patent_Stock $\left._{i, t}+1\right)=a+b_{1}$ POST $_{i, t}+b_{2} I P R_{i, t-1}+b_{3}$ POST $_{i, t} \times I P R_{i, t-1}+$ Controls $_{i, t-1}+\varepsilon_{i t}$

The dependent variable is the (natural logarithm) of (one plus) a firm's patent stock in the year t. POST is an indicator variable that takes on the value of one for years after privatization, and zero otherwise; IPR is the measure of the IPR score in the prefecture where the firm is located in year t-1; and POST $\times$ IPR is the interaction between the two variables. In model (3), the IPR dummy is a dummy variable that equals 1 if a firm is located in a high IPR protection region and 0 otherwise. Control variables include firm level characteristics measured at the end of year t-1: size (expressed as the logarithm of assets measured in RMB), intangible assets (as a fraction of total assets), return on assets (defined as net income divided by total assets), leverage (defined as total debt divided by total assets), and age (the number of years since the firm's inception). Province-level controls include GDP growth from years t-1 to $t$ (in decimals), university density in year t-1 (measured as number of four-year universities per 100,000 population), and the increase in government $R \& D$ subsidies (calculated as the increase in the amount of government R\&D subsidy from years $\mathrm{t}-1$ to $\mathrm{t}$ divided by the provincial GDP in year t-1). Standard errors are clustered by province. P-values are in parentheses. $*, * *, * * *$ indicates statistical significance at the $10 \%, 5 \%$, and $1 \%$ level, respectively. 


\begin{tabular}{|c|c|c|c|c|c|c|}
\hline DEP VAR = log of & $\begin{array}{c}\quad(1) \\
\text { Invention and } \\
\text { Utility Patent } \\
\text { Stock }+1 \\
\end{array}$ & $\begin{array}{c}\quad(2) \\
\text { Invention and } \\
\text { Utility Patent } \\
\text { Stock }+1 \\
\end{array}$ & $\begin{array}{c}\quad(3) \\
\text { Invention and } \\
\text { Utility Patent } \\
\text { Stock }+1 \\
\end{array}$ & $\begin{array}{c}(4) \\
\text { Invention } \\
\text { Patent Stock + } \\
1 \\
\end{array}$ & $\begin{array}{c}\text { (5) } \\
\text { Utility Patent } \\
\text { Stock + } 1\end{array}$ & $\begin{array}{c}\quad(6) \\
\text { Invention and } \\
\text { Utility Patent } \\
\text { Stock }+1 \\
\end{array}$ \\
\hline \multirow[t]{2}{*}{ POST } & $0.025 * *$ & $-0.138 * *$ & -0.027 & $-0.088 * *$ & -0.091 & $-0.192 * *$ \\
\hline & $(0.049)$ & $(0.037)$ & $(0.192)$ & $(0.041)$ & $(0.107)$ & $(0.034)$ \\
\hline \multirow[t]{2}{*}{ IPR } & $0.244 * *$ & -0.116 & & -0.058 & -0.131 & $-0.267 *$ \\
\hline & $(0.014)$ & $(0.236)$ & & $(0.385)$ & $(0.117)$ & $(0.099)$ \\
\hline \multirow[t]{2}{*}{$\mathrm{POST} \times \mathrm{IPR}$} & & $0.225 * *$ & & $0.138 *$ & $0.158 *$ & $0.327 * *$ \\
\hline & & $(0.036)$ & & $(0.057)$ & $(0.083)$ & $(0.024)$ \\
\hline \multirow[t]{2}{*}{ IPR dummy } & & & -0.038 & & & \\
\hline & & & $(0.133)$ & & & \\
\hline \multirow[t]{2}{*}{ POST $\times$ IPR dummy } & & & $0.071^{* *}$ & & & \\
\hline & & & $(0.016)$ & & & \\
\hline \multirow[t]{2}{*}{ Log(asset) } & $0.145^{* * *}$ & $0.137 * * *$ & $0.137 * * *$ & $0.074 * * *$ & $0.101^{* * *}$ & $0.067 * *$ \\
\hline & $(0.014)$ & $(0.000)$ & $(0.001)$ & $(0.000)$ & $(0.000)$ & $(0.014)$ \\
\hline \multirow[t]{2}{*}{ Intangible } & -0.256 & $-0.497 * *$ & $-0.499 * *$ & 0.07 & $-0.811 * * *$ & 0.372 \\
\hline & $(0.302)$ & $(0.045)$ & $(0.044)$ & $(0.708)$ & $(0.000)$ & $(0.276)$ \\
\hline \multirow[t]{2}{*}{ ROA } & $0.318^{* * *}$ & $0.316^{* * *}$ & $0.319 * * *$ & $0.092 *$ & $0.276^{* * *}$ & -0.01 \\
\hline & $(0.009)$ & $(0.000)$ & $(0.001)$ & $(0.067)$ & $(0.000)$ & $(0.886)$ \\
\hline \multirow[t]{2}{*}{ Leverage } & $-0.040 * *$ & $-0.048 * * *$ & $-0.049 * * *$ & -0.007 & $-0.043 * * *$ & 0.044 \\
\hline & $(0.040)$ & $(0.009)$ & $(0.008)$ & $(0.588)$ & $(0.008)$ & $(0.203)$ \\
\hline \multirow[t]{2}{*}{ Age } & $-0.030 *$ & $-0.039 * * *$ & $-0.039 * * *$ & $-0.041 * * *$ & $-0.014 *$ & $0.215^{* * *}$ \\
\hline & $(0.052)$ & $(0.000)$ & $(0.001)$ & $(0.000)$ & $(0.086)$ & $(0.007)$ \\
\hline \multirow[t]{2}{*}{ GDP growth } & 0.204 & $-0.584^{* *}$ & $-0.580 * *$ & $-0.571 * * *$ & -0.226 & -0.075 \\
\hline & $(0.384)$ & $(0.012)$ & $(0.013)$ & $(0.001)$ & $(0.216)$ & $(0.593)$ \\
\hline \multirow[t]{2}{*}{ University density } & $3.522 * *$ & $51.003 * * *$ & $51.576 * * *$ & $37.656 * * *$ & $33.019 * * *$ & $21.763^{*}$ \\
\hline & $(0.013)$ & $(0.000)$ & $(0.001)$ & $(0.000)$ & $(0.000)$ & $(0.054)$ \\
\hline \multirow[t]{2}{*}{ Gov't subsidy } & 59.492 & 74.302 & 74.209 & $50.783 *$ & $72.532 *$ & 8.484 \\
\hline & $(0.200)$ & $(0.106)$ & $(0.107)$ & $(0.065)$ & $(0.071)$ & $(0.596)$ \\
\hline \multirow[t]{2}{*}{ Constant } & $-3.149 * * *$ & $-2.706 * * *$ & $-2.769 * * *$ & $-1.679 * * *$ & $-1.803 * * *$ & $-1.785^{* *}$ \\
\hline & $(0.000)$ & $(0.000)$ & $(0.001)$ & $(0.000)$ & $(0.000)$ & $(0.012)$ \\
\hline Industry fixed effects & Yes & Yes & Yes & Yes & Yes & No \\
\hline Province fixed effects & Yes & Yes & Yes & Yes & Yes & No \\
\hline Firm fixed effects & No & No & No & No & No & Yes \\
\hline Observations & 5,854 & 5,854 & 5,854 & 5,854 & 5,854 & 5,854 \\
\hline R-squared & 0.235 & 0.270 & 0.27 & 0.212 & 0.242 & 0.865 \\
\hline
\end{tabular}




\section{Table 7. Matched Sample Analysis}

This table reports difference-in-difference analyses using propensity-score matched samples. Details of the matching procedure are discussed in Section II.B. Panel A compares the firm characteristics of the "treatment" sample and the "control" sample. Panel B repeats the difference-in-difference analyses as in Table 5 using the matched samples. Panel C reports regression analyses of the treatment and the control samples' patent stocks. In Panel A, Patent stock growth is the average annual growth in patent stock, measured from five years before the privatization to one year before the privatization. Ln(Assets) is the natural logarithm of total assets (measured in RMB). Intangible is the firm's intangible assets divided by total assets. ROA is the net income divided by total assets. Leverage is total debt divided by total assets. All ratios are expressed in decimal points. These variables are measured in the year before the privatization. In Panel C, Treat is an indicator variable that equals 1 for treatment firms (firms located in high IPP regions), and zero for control firms (firms located in low IPP regions). BEFORE ${ }^{-2 \&-1}$ is a dummy that equals one if a firm-year observation is from two or one year(s) before the privatization (year -2 and -1 ,) and zero otherwise. CURRENT is a dummy that equals one if a firm-year observation is from the privatization year (year 0 ), and zero otherwise. After ${ }^{1}$ is a dummy that equals one if a firm-year observation is from the year immediately after the privatization (year 1), and zero otherwise. $\mathrm{AFTER}^{2+}$ is a dummy that equals one if a firm-year observation is from the second year after privatization until the end of the window, and zero otherwise. In all panels, $*, * *, * * *$ indicate statistical significance at the $10 \%, 5 \%$, and $1 \%$ levels, respectively.

\begin{tabular}{|c|c|c|c|c|}
\hline \multicolumn{5}{|c|}{ Panel A: Differences in Pre-privatization Characteristics } \\
\hline & Treatment & Control & Difference & t-statistic \\
\hline Patent stock growth $\mathrm{t}-5$ to $\mathrm{t}-1$ & 0.372 & 0.274 & 0.098 & 0.784 \\
\hline $\log (\text { asset })_{t-1}$ & 17.462 & 17.302 & 0.159 & 1.466 \\
\hline Intangible $t_{-1}$ & 0.003 & 0.002 & 0.001 & 0.867 \\
\hline $\mathrm{ROA}_{\mathrm{t}-1}$ & 0.019 & 0.021 & -0.002 & -0.330 \\
\hline Leverage $t_{t-1}$ & 0.667 & 0.666 & 0.001 & 0.034 \\
\hline Age $t-1$ & 2.746 & 2.766 & -0.020 & -0.320 \\
\hline
\end{tabular}

Panel B: Difference-in-Difference Test

(1) Invention and Utility Patent Stock

\begin{tabular}{lcccc}
\hline & $\begin{array}{c}\text { Treatment } \\
\text { (High IPP) }\end{array}$ & $\begin{array}{c}\text { Control } \\
\text { (Low IPP) }\end{array}$ & $\begin{array}{c}\text { Diff } \\
\text { (Treatment-Control) }\end{array}$ & Diff-In-Diff \\
\cline { 2 - 5 } Before & 0.207 & 0.154 & 0.052 & \\
After & 1.198 & 0.537 & $0.661^{*}$ & $0.609^{* *}$ \\
\hline After-Before & $0.991^{* * *}$ & $0.383^{* * *}$ & & \\
\hline (2) Invention Patent Stock & & & & Diff-In-Diff \\
& Treatment & Control & Diff & \\
Before & (High IPP) & (Low IPP) & (Treatment-Control) & \\
After & 0.041 & 0.039 & 0.002 & $0.183^{* *}$ \\
\hline After-Before & 0.293 & 0.11 & & $0.181^{* * *}$ \\
\hline
\end{tabular}

(3) Utility Patent Stock 


\begin{tabular}{lcccc} 
& $\begin{array}{c}\text { Treatment } \\
(\text { High IPP) }\end{array}$ & $\begin{array}{c}\text { Control } \\
\text { (Low IPP) }\end{array}$ & $\begin{array}{c}\text { Diff } \\
\text { (Treatment-Control) }\end{array}$ & Diff-In-Diff \\
\cline { 2 - 5 } Before & 0.166 & 0.116 & 0.05 & \\
After & 0.905 & 0.427 & $0.478^{*}$ & \\
\hline After-Before & $0.739^{* * *}$ & $0.312^{* * *}$ & & $0.428^{*}$ \\
\hline
\end{tabular}

Panel C: Regression Results

\begin{tabular}{|c|c|c|c|}
\hline Dependent Variable & $\begin{array}{l}\text { Ln (Invention and utility } \\
\text { patent stock }+1 \text { ) }\end{array}$ & Ln (Invention patent stock + 1) & Ln (Utility patent stock +1 ) \\
\hline \multirow[t]{2}{*}{ Treat $\times$ Before $^{-2 \&-1}$} & 0.0052 & -0.007 & 0.0144 \\
\hline & $(0.820)$ & $(0.520)$ & $(0.470)$ \\
\hline \multirow[t]{2}{*}{ Treat $\times$ Current } & 0.0088 & -0.0025 & 0.0176 \\
\hline & $(0.790)$ & $(0.880)$ & $(0.560)$ \\
\hline \multirow[t]{2}{*}{ Treat $\times$ After $^{1}$} & 0.0431 & 0.011 & 0.0421 \\
\hline & $(0.250)$ & $(0.530)$ & $(0.210)$ \\
\hline \multirow[t]{2}{*}{ Treat $\times$ After $^{2+}$} & $0.0783^{* * *}$ & $0.0461 * * *$ & $0.0627 * * *$ \\
\hline & $(0.000)$ & $(0.000)$ & $(0.010)$ \\
\hline \multirow[t]{2}{*}{ Before ${ }^{-2 \&-1}$} & $0.0476^{* * *}$ & $0.0195 * *$ & $0.0327 * *$ \\
\hline & $(0.000)$ & $(0.010)$ & $(0.010)$ \\
\hline \multirow[t]{2}{*}{ Current } & $0.0802^{* * *}$ & $0.0283 * *$ & $0.0592 * * *$ \\
\hline & $(0.000)$ & $(0.010)$ & $(0.000)$ \\
\hline \multirow[t]{2}{*}{ After ${ }^{1}$} & $0.0892 * * *$ & $0.0308^{* * *}$ & $0.0672 * * *$ \\
\hline & $(0.000)$ & $(0.010)$ & $(0.000)$ \\
\hline \multirow[t]{2}{*}{ After $^{2+}$} & $0.1356^{* * *}$ & $0.0484 * * *$ & $0.1093^{* * *}$ \\
\hline & $(0.000)$ & $(0.000)$ & $(0.000)$ \\
\hline \multirow[t]{2}{*}{ Treat } & 0.0131 & 0.0056 & 0.0085 \\
\hline & $(0.260)$ & $(0.290)$ & $(0.410)$ \\
\hline \multirow[t]{2}{*}{ Constant } & $0.0470 * * *$ & $0.0091^{* * *}$ & $0.0396 * * *$ \\
\hline & $(0.000)$ & $(0.010)$ & $(0.000)$ \\
\hline Observations & 8,081 & 8,081 & 8,081 \\
\hline R-squared & 0.026 & 0.018 & 0.021 \\
\hline
\end{tabular}




\section{Table 8. Instrumental Variables (IV) Regression}

This table reports IV regression results. In the first stage, we predict IPR scores using two instrumental variables: Christian College (the number of colleges founded by Christian missionaries in a province before 1920) and British Settlement (a dummy variable that equals one if the province had a British concession in the Qing Dynasty and zero otherwise). In the second stage, the unit of observation is (as in Table 6) annual observations of each privatized firm for the five years before and the five years after the privatization. The dependent and independent variables are identical to those in regressions (1) through (3) of Table 6, with the exception that we employ the instrumented value for the IPR protection measure. P-values are reported in parentheses. ${ }^{*}, * *, * * *$ indicates statistical significance at the $10 \%, 5 \%$, and $1 \%$ levels, respectively.

\begin{tabular}{lc}
\hline Panel A: First Stage Results & \\
\hline DEPVAR $=$ & IPR \\
\hline Christian College & $0.017^{* * *}$ \\
& $(0.000)$ \\
British Settlement & $0.031^{* * *}$ \\
& $(0.000)$ \\
Gov't subsidy & -8.891 \\
& $(0.266)$ \\
University density & $3.044^{* * *}$ \\
& $(0.000)$ \\
GDP growth & $0.681^{* * *}$ \\
& $(0.000)$ \\
Observations & 5,854 \\
R-squared & 0.226 \\
Partial-F test for IVs & 143.84 \\
& $(\mathrm{p}=0.000)$ \\
\hline
\end{tabular}

Panel B: Second Stage Results

(1)

Invention and Utility Patent Stock +1

\begin{tabular}{lc}
\hline POST & $-0.340^{* *}$ \\
& $(0.049)$ \\
IPR (IV) & 0.448 \\
& $(0.156)$ \\
POST × IPR (IV) & $0.523^{* *}$ \\
& $(0.048)$ \\
Controls & Yes \\
Observations & 5,854 \\
R-squared & 0.234 \\
Sargan-Hansen J statistic & 1.715 \\
(Over-identifying restrictions) & $(\mathrm{p}=0.424)$
\end{tabular}

(2)

(3) Invention Patent Stock + $1 \quad$ Utility Patent Stock + 1

$-0.206$

$(0.162)$

(0.064)

(0.529)

$(0.502)$

$0.327 *$

$0.344^{*}$

(0.097)

Yes

5,854

0.209

0.717

4.251

$(\mathrm{p}=0.699)$ 


\section{Table 9. Patent Quality}

The table presents global patent application and citation data for the 331 publicly listed firms in China with the most Chinese patents. Of these 331 firms, 162 are SOEs (49\%) and 169 (51\%) private enterprises. "Citations received per patent" is the number of citations received worldwide per patent family owned by each firm as of year-end 2014. "IPC groups per patent" is the mean number of IPC groups that each patent family has been assigned to (a proxy for patent scope). "\% patents active in U.S./Japan/European Patent Offices (EPO)" is the fraction of a firm's patent families awarded through that date that have patents that are pending and/or are granted in the respective patent offices as of year-end 2014. "\% patent active in WIPO" is the share of the firm's patents active under the Patent Cooperation Treaty as of year-end 2014. We examine these patterns using all patent families (in Panel A), those first published between the beginning of 1990 and the end of 2005 (Panel B), and those first published between 2006 and 2014 (Panel C).*, **, *** indicates statistical significance at the $10 \%, 5 \%$, and $1 \%$ level using a one-tailed test, respectively.

\begin{tabular}{|c|c|c|c|c|}
\hline \multicolumn{5}{|c|}{ Panel A: Entire sample: Patents published between 1990 - 2014} \\
\hline & $\underline{\text { Private }}$ & $\underline{\mathrm{SOE}}$ & $\underline{\text { t-stat (diff) }}$ & \\
\hline Citations received per patent & 0.76 & 0.47 & 2.74 & $* * *$ \\
\hline IPC groups per patent & 1.81 & 1.66 & 3.15 & $* * *$ \\
\hline \% patents active in U.S. & $6.1 \%$ & $4.2 \%$ & 2.40 & $* *$ \\
\hline$\%$ patents active in Japan & $1.6 \%$ & $1.9 \%$ & -0.90 & \\
\hline \% patents active in EPO & $0.6 \%$ & $0.9 \%$ & -1.21 & \\
\hline$\%$ patents active in WIPO & $1.4 \%$ & $0.5 \%$ & 3.15 & $* * *$ \\
\hline \multicolumn{5}{|c|}{ Panel B: Period 1 -- Patents published between 1990 - 2005} \\
\hline & $\underline{\text { Private }}$ & $\underline{\mathrm{SOE}}$ & $\underline{\text { t-stat (diff) }}$ & \\
\hline Citations received per patent & 2.89 & 1.17 & 4.06 & $* * *$ \\
\hline IPC groups per patent & 1.89 & 1.77 & 1.04 & \\
\hline \% patents active in U.S. & $17.6 \%$ & $9.9 \%$ & 2.81 & $* * *$ \\
\hline$\%$ patents active in Japan & $5.6 \%$ & $3.8 \%$ & 1.20 & \\
\hline \% patents active in EPO & $0.3 \%$ & $0.5 \%$ & -0.52 & \\
\hline \% patents active in WIPO & $0.0 \%$ & $0.0 \%$ & . & \\
\hline \multicolumn{5}{|c|}{ Panel C: Period 2 -- Patents published between 2006 - 2014} \\
\hline & $\underline{\text { Private }}$ & $\underline{\mathrm{SOE}}$ & $\underline{\mathrm{t}-\text { stat (diff) }}$ & \\
\hline Citations received per patent & 0.30 & 0.19 & 2.17 & $* *$ \\
\hline IPC groups per patent & 1.80 & 1.61 & 3.31 & $* * *$ \\
\hline \% patents active in U.S. & $3.6 \%$ & $2.0 \%$ & 2.76 & $* * *$ \\
\hline$\%$ patents active in Japan & $0.7 \%$ & $1.2 \%$ & -1.84 & $* *$ \\
\hline \% patents active in EPO & $0.6 \%$ & $1.0 \%$ & -1.31 & \\
\hline$\%$ patents active in WIPO & $1.8 \%$ & $0.7 \%$ & 2.72 & $* * *$ \\
\hline
\end{tabular}




\section{Appendix 1 - Data Sources}

This table lists the data sources used in this paper.

\begin{tabular}{|c|c|c|}
\hline & Source & Data Provider \\
\hline IPR Protection & Urban Competitiveness Report Blue Book & The Chinese Academy of Social Sciences \\
\hline Firm level patents & http://epub.sipo.gov.cn/gjcx.jsp & $\begin{array}{l}\text { The Chinese State Intellectual Property Office } \\
\text { (CSIPO) }\end{array}$ \\
\hline \multirow[t]{2}{*}{ SOE Privatization } & 1. CSMAR & CSMAR \\
\hline & 2. Industrial Enterprises Database & The National Statistical Bureau of China \\
\hline Provincial level controls & China Statistical Yearbooks & The National Statistical Bureau of China \\
\hline \multirow[t]{2}{*}{ Firm level controls } & 1. CSMAR & \\
\hline & 2. Industrial Enterprises Database & \\
\hline
\end{tabular}




\section{Conflict of Interest Statements}

Lily Fang declares that no external funding has been used for this research and that she has no conflict of interest.

Josh Lerner declares that no external funding has been used for this research and that he has no conflict of interest.

Chaopeng Wu declares that no external funding has been used for this research and that he has no conflict of interest. 